\title{
The greenhouse gas balance of a drained fen peatland is mainly controlled by land-use rather than soil organic carbon content
}

\author{
T. Eickenscheidt ${ }^{1,2}$, J. Heinichen ${ }^{1,2}$, and M. Drösler ${ }^{1}$ \\ ${ }^{1}$ University of Applied Sciences Weihenstephan-Triesdorf, Department of Vegetation Ecology, Weihenstephaner Berg 4, \\ 85354 Freising, Germany \\ ${ }^{2}$ Technische Universität München, Department of Restoration Ecology, Emil-Ramann-Str. 6, 85354 Freising, Germany \\ Correspondence to: T. Eickenscheidt (tim.eickenscheidt@hswt.de)
}

Received: 5 February 2015 - Published in Biogeosciences Discuss.: 2 April 2015

Accepted: 18 August 2015 - Published: 2 September 2015

\begin{abstract}
Drained organic soils are considered to be hotspots for greenhouse gas (GHG) emissions. Arable lands and intensively used grasslands, in particular, have been regarded as the main producers of carbon dioxide $\left(\mathrm{CO}_{2}\right)$ and nitrous oxide $\left(\mathrm{N}_{2} \mathrm{O}\right)$. However, GHG balances of former peatlands and associated organic soils not considered to be peatland according to the definition of the Intergovernmental Panel on Climate Change (IPCC) have not been investigated so far. Therefore, our study addressed the question to what extent the soil organic carbon (SOC) content affects the GHG release of drained organic soils under two different landuse types (arable land and intensively used grassland). Both land-use types were established on a Mollic Gleysol (labeled $\mathrm{C}_{\text {medium}}$ ) as well as on a Sapric Histosol (labeled $\mathrm{C}_{\text {high }}$ ). The two soil types differed significantly in their SOC contents in the topsoil $\left(\mathrm{C}_{\text {medium }}\right.$ : $9.4-10.9 \%$ SOC; $\mathrm{C}_{\text {high }}$ : $16.1-$ $17.2 \%$ SOC). We determined GHG fluxes over a period of 1 or 2 years in case of $\mathrm{N}_{2} \mathrm{O}$ or methane $\left(\mathrm{CH}_{4}\right)$ and $\mathrm{CO}_{2}$, respectively. The daily and annual net ecosystem exchange (NEE) of $\mathrm{CO}_{2}$ was determined by measuring NEE and the ecosystem respiration $\left(R_{\mathrm{ECO}}\right)$ with the closed dynamic chamber technique and by modeling the $R_{\mathrm{ECO}}$ and the gross primary production (GPP). $\mathrm{N}_{2} \mathrm{O}$ and $\mathrm{CH}_{4}$ were measured with the static closed chamber technique. Estimated NEE of $\mathrm{CO}_{2}$ differed significantly between the two land-use types, with lower NEE values ( -6 to $1707 \mathrm{~g} \mathrm{CO}_{2}-\mathrm{C} \mathrm{m}^{-2} \mathrm{yr}^{-1}$ ) at the arable sites and higher values (1354 to $1823 \mathrm{~g} \mathrm{CO}_{2}$ $\mathrm{C} \mathrm{m}^{-2} \mathrm{yr}^{-1}$ ) at the grassland sites. No effect on NEE was found regarding the SOC content. Significantly higher annual $\mathrm{N}_{2} \mathrm{O}$ exchange rates were observed at the arable sites $\left(0.23-0.86 \mathrm{~g} \mathrm{~N} \mathrm{~m}^{-2} \mathrm{yr}^{-1}\right)$ than at the grassland sites $(0.12-$
\end{abstract}

$0.31 \mathrm{~g} \mathrm{~N} \mathrm{~m}^{-2} \mathrm{yr}^{-1}$ ). Furthermore, $\mathrm{N}_{2} \mathrm{O}$ fluxes from the $\mathrm{C}_{\text {high }}$ sites significantly exceeded those of the $\mathrm{C}_{\text {medium }}$ sites. $\mathrm{CH}_{4}$ fluxes were found to be close to zero at all plots. Estimated global warming potential, calculated for a time horizon of 100 years $\left(\mathrm{GWP}_{100}\right)$ revealed a very high release of GHGs from all plots ranging from 1837 to $7095 \mathrm{~g} \mathrm{CO}_{2 \text { eq. }} \mathrm{m}^{-2} \mathrm{yr}^{-1}$. Calculated global warming potential (GWP) values did not differ between soil types and partly exceeded the IPCC default emission factors of the Tier 1 approach by far. However, despite being subject to high uncertainties, the results clearly highlight the importance of adjusting the IPCC guidelines for organic soils not falling under the definition in order to avoid a significant underestimation of GHG emissions in the corresponding sectors of the national climate reporting. Furthermore, the present results revealed that mainly the type of land-use, including the management type, and not the SOC content is responsible for the height of GHG exchange from intensive farming on drained organic soils.

\section{Introduction}

Most natural peatlands act as a sink for atmospheric carbon dioxide $\left(\mathrm{CO}_{2}\right)$ and as a source for methane $\left(\mathrm{CH}_{4}\right)$ (Blodau, 2002; Whalen, 2005; Drösler et al., 2008). The net climate effect of natural peatlands regarding the greenhouse gas (GHG) fluxes, however, is close to zero (Drösler et al., 2008). In the last century, drainage and the intensification of agriculture turned European peatlands into hot spots for GHG emissions (Drösler et al., 2008). Increased $\mathrm{CO}_{2}$ and nitrous oxide $\left(\mathrm{N}_{2} \mathrm{O}\right)$ emissions have been observed from drained peat- 
lands as a result of enhanced decomposition of organic matter (Martikainen et al., 1993; Silvola et al., 1996). The gases mentioned $\left(\mathrm{CO}_{2}, \mathrm{CH}_{4}\right.$ and $\left.\mathrm{N}_{2} \mathrm{O}\right)$ act as climatically relevant greenhouse gases (IPCC, 2007). Additionally, $\mathrm{N}_{2} \mathrm{O}$ and $\mathrm{CH}_{4}$ contributes to the chemical destruction of stratospheric ozone (Crutzen, 1979; Solomon, 1999).

Through the ratification of several international agreements on climate protection (e.g., UNFCCC 1992; Kyoto protocol 1997 - specified by the Bonn Agreements and Marrakesh Accords; several EU decisions) Germany is obliged to publish annual national greenhouse gas emissions inventories according to the Intergovernmental Panel on Climate Change (IPCC) guidelines. However, the national climate reporting in the Land-use, Land-Use Change and Forestry (LULUCF) sector as well in the Agriculture, Forestry and Other Land-uses (AFOLU) sector is challenging with regard to organic soils. This is mainly because reliable measurements of GHGs from temperate drained peatlands are rare and observed GHG fluxes show a large temporal and spatial variability ranging from -2 to $31 \mathrm{tCO}_{2}-\mathrm{Cha}^{-1} \mathrm{yr}^{-1}$ and 2 to $38 \mathrm{~kg} \mathrm{~N}_{2} \mathrm{O}-\mathrm{N} \mathrm{ha}^{-1} \mathrm{yr}^{-1}$ (IPCC, 2014). Furthermore, the definition of Histosols is complex (Couwenberg, 2011), and several national and international classification systems exist for organic soils. For the climate reporting under LULUCF/AFOLU, the IPCC guidelines require at least $\geq 10 \mathrm{~cm}$ thickness of the soil or peat layer and an organic carbon $\left(\mathrm{C}_{\text {org }}\right)$ content of $\geq 12 \%$ in the case of a soil thickness $\leq 20 \mathrm{~cm}$ for peat soils. Thus, the IPCC definition of peat soils is broader than the definition of Histosols in the world reference base for soil resources (WRB, 2008). In the German classification system (KA5) (Ad-hoc-AG Boden, 2005), a distinction is made between soil horizons with $\geq 30 \%$ soil organic matter (SOM) content (called organic horizon) and those, containing 15-30\% SOM (called anmoor horizon). Particularly at the boundary between mineral and organic soils, the conversion from $\mathrm{C}_{\text {org }}$ to SOM leads to uncertainties due to different conversion factors which are commonly used for mineral soils and peat soils according to the KA5 (Tiemeyer et al., 2013). Depending on the conversion factor (1.72 for mineral soils or 2 for peat soils), the maximum limit of the IPCC requirement is between 21 and $24 \%$ SOM (Tiemeyer et al., 2013). To date, soils which are, by definition in the transition between mineral and organic soils were mostly neglected in the national GHG inventory of most countries (Leiber-Sauheitl et al., 2014). In the Danish greenhouse gas inventory, for example, GHG emissions from very thin and shallow organic soils, which do not meet the definition of organic soils according to the IPCC, were also considered. Due to a lack of information about the release of the GHG emissions of those soils, a fixed emission factor, half as much as for typical organic soils $\left(>12 \% \mathrm{C}_{\text {org }}\right)$, has been introduced in Denmark for soils containing 6-12\% organic carbon (Nielsen et al., 2012).

According to estimates, peatlands in Germany account for approximately $4.9 \%$ of the national GHG emissions al- though they only account for $5.1 \%$ of the total area (NIR, 2010; Drösler et al., 2011). Drained peatlands even represent the largest single source for GHG emissions outside the energy sector in Germany (Drösler et al., 2011; NIR, 2010). Hence, according to the IPCC guidelines, drained peatlands are identified as a key category which results in Germany being obliged to calculate the annual GHG emission inventory on the basis of nationally specific emission factors (EF; Tier 2 or Tier 3 methods). The main reason for the critical climate balance is caused by the fact that more than two-thirds of the German peatlands are intensively used as grassland or arable land (Drösler et al., 2008). Both landuse types have been regarded as the main producers of $\mathrm{CO}_{2}$ and $\mathrm{N}_{2} \mathrm{O}$ from farmed organic soils (Kasimir-Klemedtsson et al., 1997; Kroeze et al., 1999; Drösler et al., 2008; International Peat Society, 2008). Highest GHG emissions from drained organic soils were related to management activities such as tillage and fertilization, which enhance microbial SOM decomposition and nitrogen turnover (Kandel et al., 2013). Beside management practices, several other physical and chemical factors control the intensity of mineralization processes (Heller and Zeitz, 2012) in which soil temperature and soil moisture are considered to be the primary regulators for $\mathrm{CO}_{2}$ emissions from soils (Silvola et al., 1996; Maljanen et al., 2001; Hardie et al., 2011). However, recent studies have shown that in particular the SOM quality and its labile and more recalcitrant fractions act as key variables affecting the decomposability of SOM, and thus they control $\mathrm{CO}_{2}$ fluxes from peatlands (Byrne and Farrell, 2005; Heller and Zeitz, 2012; Leifeld et al., 2012). Beside the macromolecular organic composition (e.g., polysaccharides, lignin, and aliphatic biopolymers) of the peat-forming vegetation, the SOM quality of peat strongly depends on hydrological and geomorphological building conditions during peat formation (Heller and Zeitz, 2012). Additionally, peat and SOM quality is strongly affected by human impact, which leads to peat shrinking, secondary decomposition and mineralization (Heller and Zeitz, 2012). It can be assumed that with increasing peat humification, aggregation and organomineral association gain in importance in the SOM stabilization. Thus, a decrease in $\mathrm{CO}_{2}$ emissions from soils which are by definition at the transition between mineral soils and peat, can be expected compared to peat soils with higher SOM contents. The objective of this study was to quantify GHG emissions from arable lands and grasslands on two types of drained organic soils with different $\mathrm{C}_{\text {org }}$ contents in southern Germany. We hypothesize (i) that GHG emissions significantly increase with increasing soil organic carbon (SOC) content in the soil and (ii) that GHG emissions from arable soils exceed GHG emissions from intensively managed grassland soils. 


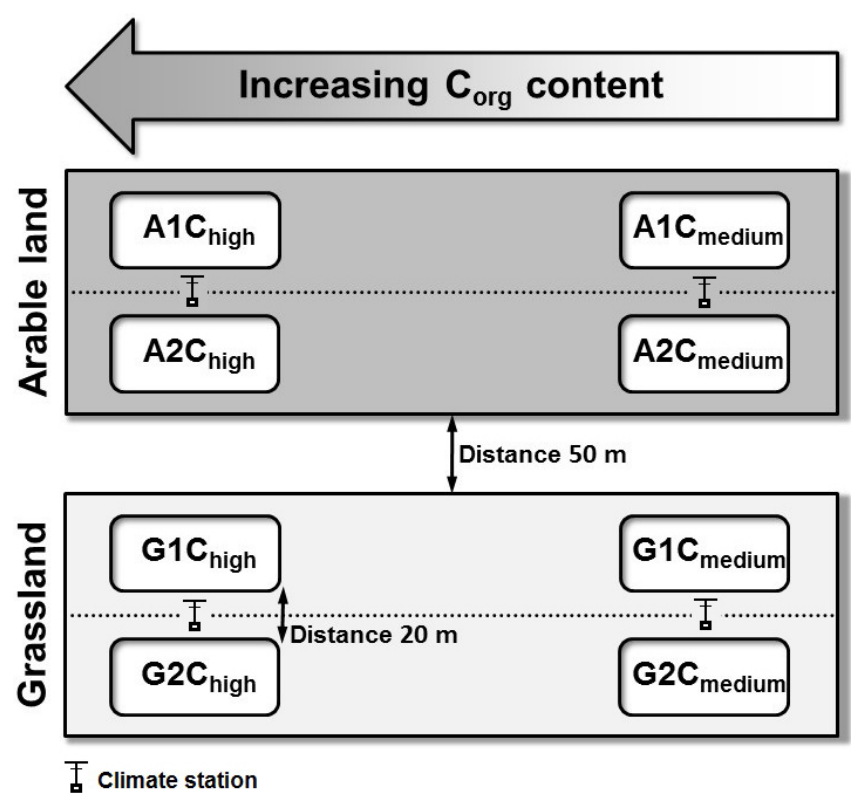

Figure 1. Schema of the experimental design.

\section{Material and methods}

\subsection{Study area and experimental design}

The study was conducted at a drained fen peatland $30 \mathrm{~km}$ northeast of Munich (Freisinger Moos; $48^{\circ} 21^{\prime} \mathrm{N}, 11^{\circ} 41^{\prime} \mathrm{E}$; 450 ma.s.l.). From 1914 onwards, the Freisinger Moos (FSM) was systematically drained for intensive cultivation (Zehlius-Eckert et al., 2003). Today about $40 \%$ of the whole area (1570 ha) is used as grassland and $20 \%$ as arable land (Schober et al., 2008).

According to the climate station at Munich airport, located $7 \mathrm{~km}$ east of the study sites, the 30 -year mean annual temperature was $8.7^{\circ} \mathrm{C}$ and the mean annual precipitation was $834 \mathrm{~mm}$ (1981-2010). Annual atmospheric $\mathrm{N}$ deposition amounted to 6.22 and $7.20 \mathrm{~kg} \mathrm{~N} \mathrm{ha}^{-1} \mathrm{yr}^{-1}$ in 2010 and 2011. Data of $\mathrm{N}$ deposition were collected by the Bavarian State Institute of Forestry at a German Level II monitoring plot (Forest Intensive Monitoring Programme of the UNECE), located at a distance of $7 \mathrm{~km}$ to the sites investigated.

In October 2009, we selected two adjacent areas, one used as intensive grassland and the other as arable land. Both areas are characterized by a distinct gradient in their soil organic carbon (SOC) content in the topsoil (Table 1), which increases from the southeast to the northwest. In March 2010 the arable land was split into two halves to simulate two different crop rotations (maize (Zea mays) and oat (Avena sativa); see Table 3) along the SOC gradient (labeled A1 and A2). At the grassland area a similar design was implemented to investigate the effect of two different organic fertilizers (labeled G1, fertilized with cattle slurry, and G2, fertilized with biogas digestate). Within these areas we selected two sites with maximally different SOC contents per land use type (Fig. 1). According to the WRB (2006), soil types at the sites were classified as Mollic Gleysol (labeled $\mathrm{C}_{\text {medium }}$ ) and as Sapric Histosol (labeled $\mathrm{C}_{\text {high }}$ ) (N. Roßkopf, personal communication, 2010). At each site two plots were selected according to the management type (Fig. 1). A detailed description of the experimental design of the grassland sites and the chemical and physical composition of the applied fertilizers is given in Eickenscheidt et al. (2014b) and Table 2. The arable land was managed according to organic-farming criteria but without any fertilization during the investigated period.

At each plot, three PVC collars for GHG measurements (inside dimension $75 \times 75 \mathrm{~cm}$ ) were permanently inserted $10 \mathrm{~cm}$ into the soil at a distance of $1.5-2 \mathrm{~m}$ to each other. In the case of management activities, collars were removed for a short period on the arable land. To prevent oscillations of the peat through movements during the measurements, boardwalks were installed. In March 2010, climate stations were set up at each site, midway between the two plots (see Fig. 1; for the arable land, climate stations represent temperatures from the management of the A1 plots), for the continuous recording (every $0.5 \mathrm{~h}$ ) of air temperature $\left(T_{\text {air }}\right)$ and humidity at $20 \mathrm{~cm}$ above soil surface; in addition, soil temperature was measured at a depth of $-2,-5$ and $-10 \mathrm{~cm}\left(\mathrm{ST}_{2}, 5,10\right)$ and soil moisture content was measured at a depth of $-5 \mathrm{~cm}$. In addition, two further climate stations, additionally equipped with sensors to measure air temperature at $200 \mathrm{~cm}$ above the soil surface and photon flux density of the photosynthetically active radiation (PAR), were operated in close proximity $(1.5 \mathrm{~km})$ to the areas investigated. For measuring the groundwater table, plastic perforated tubes (JK casings DN 50, $60 \mathrm{~mm}$ diameter, $1 \mathrm{~m}$ length) were inserted close to each collar for the plot-specific measurements of groundwater $(\mathrm{GW})$ tables during gas flux measurements at the grassland plots. On the arable land only, three tubes were inserted between the two plots of the same soil type. In April 2010, we equipped one tube per plot or, in the case of the arable land one tube per soil type, with a water level logger (Type MiniDiver, Schlumberger water services), which recorded the water tables every $15 \mathrm{~min}$. Additionally, to the recorded data, plot-specific soil temperatures at three soil depths $(-2,-5$ and $-10 \mathrm{~cm})$ were determined with penetration thermometers at the beginning and end of each gas flux measurement.

\subsection{Biomass yield, soil sampling and laboratory analyses}

Crop and grass yield was determined by harvesting the biomass inside the PVC collars with scissors at each harvesting event (same cutting height as that used by the farmers) (Table 3). To determine the annual crop or grass yield, samples were oven-dried at $60^{\circ} \mathrm{C}$ for $48 \mathrm{~h}$ and the phytomass of each harvesting event per year was summed. To determine 
Table 1. Physical and chemical properties of the investigated plots.

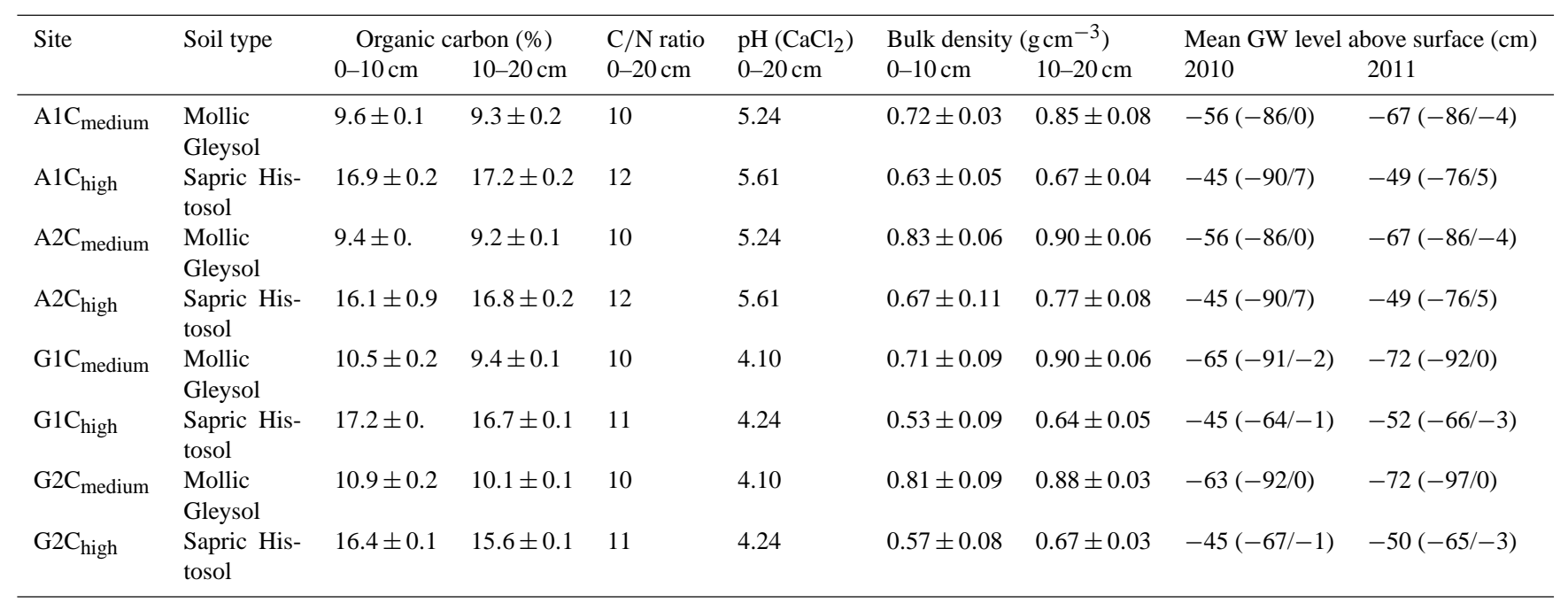

Values presented are means \pm SD.

Values in brackets are minimum and maximum values.

A: arable land.

G: grassland.

Table 2. Physical and chemical properties of the applied slurries and digestates (data derived from Eickenscheidt et al., 2014b).

\begin{tabular}{|c|c|c|c|c|c|c|c|c|}
\hline & \multicolumn{4}{|c|}{ Cattle slurry } & \multicolumn{4}{|c|}{ Biogas digestate } \\
\hline & 1. & 2. & 3. & 4. & 1. & 2. & 3. & 4. \\
\hline & $\begin{array}{l}\text { Application } \\
\text { (14 June 2010) }\end{array}$ & $\begin{array}{l}\text { Application } \\
\text { (25 August 2010) }\end{array}$ & $\begin{array}{l}\text { Application } \\
(27 \text { May 2011) }\end{array}$ & $\begin{array}{l}\text { Application } \\
(22 \text { September 2011) }\end{array}$ & $\begin{array}{l}\text { Application } \\
\text { (14 June 2010) }\end{array}$ & $\begin{array}{l}\text { Application } \\
\text { (25 August 2010) }\end{array}$ & $\begin{array}{l}\text { Application } \\
(27 \text { May 2011) }\end{array}$ & $\begin{array}{l}\text { Application } \\
\text { (22 September 2011) }\end{array}$ \\
\hline $\begin{array}{l}\text { Fertilizer } \\
\text { quantity } \\
\left(\mathrm{m}^{3} \mathrm{ha}^{-1}\right)\end{array}$ & 20 & 20 & 25 & 20 & 20 & 20 & 25 & 20 \\
\hline $\begin{array}{l}\text { Total } \\
\text { nitrogen } \\
\left(\mathrm{kg} \mathrm{ha}^{-1}\right)\end{array}$ & 47 & 64 & 70 & 85 & 49 & 52 & 78 & 35 \\
\hline $\begin{array}{l}\mathrm{NO}_{3}^{-} \\
\left(\mathrm{kg} \mathrm{Nha}^{-1}\right)\end{array}$ & 0 & 0 & 0 & 0 & 0 & 0 & 0 & 0 \\
\hline $\begin{array}{l}\mathrm{NH}_{4}^{+} \\
\left(\mathrm{kg} \mathrm{Nha}^{-1}\right)\end{array}$ & 20 & 28 & 23 & 33 & 22 & 28 & 51 & 17 \\
\hline $\mathrm{C} / \mathrm{N}$ ratio & 12 & 11 & 11 & 9 & 8 & 7 & 2 & 5 \\
\hline $\mathrm{pH}\left(\mathrm{CaCl}_{2}\right)$ & - & - & 6.8 & 7.0 & - & - & 7.7 & 7.4 \\
\hline
\end{tabular}

the total carbon $\left(\mathrm{C}_{\text {tot }}\right)$ and total nitrogen $\left(\mathrm{N}_{\text {tot }}\right)$ content, the total phytomass was milled $(0.5 \mathrm{~mm})$ and a pooled and homogenized sample from each PVC collar and harvesting event was analyzed by the AGROLAB Labor GmbH (Bruckberg, Germany).

Mineral $\mathrm{N}\left(\mathrm{N}_{\min }=\mathrm{NH}_{4}^{+}-\mathrm{N}+\mathrm{NO}_{3}^{-}-\mathrm{N}\right)$ contents of each plot were determined according to VDLUFA (1997). Samples were taken during every $\mathrm{CH}_{4} / \mathrm{N}_{2} \mathrm{O}$ gas flux measurement. For the determination of $\mathrm{C}_{\text {tot }}$ and organic carbon $\left(\mathrm{C}_{\text {org }}\right)$, a mixed soil sample of nine individual samples was collected close to each collar at two soil depths $(0-10,10$ $20 \mathrm{~cm}$ ) using an auger with a diameter of $3 \mathrm{~cm}$. After having been dried for $72 \mathrm{~h}$ at $40^{\circ} \mathrm{C}$, soil samples were sieved to $2 \mathrm{~mm}$ to remove stones and living roots. Analyses were conducted at the Division of Soil Science and Site Science (Humbold Universität zu Berlin, Germany). For the determination of bulk density and porosity, three undisturbed core cutter samples $\left(100 \mathrm{~cm}^{3}\right)$ were randomly taken at four depths $(0-5,5-10,10-15,15-20 \mathrm{~cm})$ for each plot.

\subsection{GHG measurements}

We measured fluxes of $\mathrm{N}_{2} \mathrm{O}$ and $\mathrm{CH}_{4}$ every second week from December 2009 to January 2012 using the static manual chamber method (Livingston and Hutchinson; 1995). We used opaque chambers $(0.78 \mathrm{~m} \times 0.78 \mathrm{~m} \times 0.5 \mathrm{~m}$; Psplastic, Eching, Germany), which were configured according to Drösler (2005), having two handles at the top, a permanent thermometer for chamber inside temperature (MiniThermometer, TFA), and a closed-cell rubber tube at the bottom to ensure airtightness when the chamber was positioned on the collars. Furthermore, a vent close to the chamber bottom was connected to a $100 \mathrm{~cm}$ PVC tube (4 mm wide) to avoid pressure differences during chamber closure and a rub- 
Table 3. Date and type of conducted management events.

\begin{tabular}{|c|c|c|c|c|}
\hline Date & Julian day & $\begin{array}{l}\text { Management events } \\
\text { A1 }\end{array}$ & A2 & G \\
\hline 24 September 2009 & - & seed sowing (Secale cereale) & seed sowing (Secale cereale) & - \\
\hline 30 March 2010 & 89 & - & $\begin{array}{l}\text { plowing and seed sowing } \\
\text { (Avena sativa and } 15 \% \\
\text { Vicia faba minor) }\end{array}$ & - \\
\hline 28 April 2010 & 118 & plowing & - & - \\
\hline 30 April 2010 & 120 & seed sowing (Zea mays) & - & - \\
\hline 24 May 2010 & 144 & grubbing & - & harvesting \\
\hline 11 June 2010 & 162 & grubbing & - & - \\
\hline 14 June 2010 & 165 & - & - & manuring \\
\hline 28 August 2010 & 240 & - & milling & - \\
\hline 4 September 2010 & 247 & - & - & - \\
\hline 23 September 2010 & 266 & - & - & $\begin{array}{l}\text { herbicide for common } \\
\text { sorrel (Rumex acetosa) }\end{array}$ \\
\hline 15 October 2010 & 288 & harvesting & - & - \\
\hline 30 October 2010 & 303 & mulching & - & - \\
\hline 16 March 2011 & 440 & - & - & leveling \\
\hline 1 April 2011 & 456 & $\begin{array}{l}\text { plowing and seed sowing } \\
\text { (Avena sativa and } 20 \% \text { Vicia } \\
\text { sativa) }\end{array}$ & - & - \\
\hline 18 April 2011 & 473 & - & plowing & - \\
\hline 1 August 2011 & 578 & - & - & harvesting \\
\hline 16 August 2011 & 593 & harvesting & - & - \\
\hline 18 August 2011 & 595 & milling & - & - \\
\hline 27 August 2011 & 604 & $\begin{array}{l}\text { plowing and seed sowing } \\
\text { (Secale cereale) }\end{array}$ & - & - \\
\hline 13 September 2011 & 621 & - & - & harvesting \\
\hline 22 September 2011 & 630 & - & - & manuring \\
\hline 28 September 2011 & 636 & - & harvesting & - \\
\hline
\end{tabular}

ber valve (M20 cable gland, Kleinhuis) for the extraction of gas samples was installed at the top of the chamber additionally ensuring pressure release during chamber placement (Elsgaard et al., 2012). At periods when the vegetation grew higher than the chamber height $(0.5 \mathrm{~m})$, extensions were used between the collar and chamber (white, opaque; volume varied between 309 and $1236 \mathrm{~L}$ ). $\mathrm{N}_{2} \mathrm{O}$ and $\mathrm{CH}_{4}$ gas flux rates were calculated from the linear change in gas concentration over time (four gas samples; sampling time was 0, 20, 40 and 60 minutes or $0,40,80,120 \mathrm{~min}$ in the case of two or more extensions), considering chamber air temperature and atmospheric pressure. Gas fluxes were accepted when the linear regression was significant $(P \leq 0.05)$. In the case of small $\mathrm{N}_{2} \mathrm{O}$ or $\mathrm{CH}_{4}$ fluxes, fluxes were also accepted if the coefficient of determination was $\geq 0.90$ and the regression slope was between -1 and $1 \mathrm{ppb} \min ^{-1}$. The cumulative annual 
mean exchange rate was calculated by linear interpolation between the measurement dates. To minimize diurnal variation in the flux pattern, $\mathrm{N}_{2} \mathrm{O}$ and $\mathrm{CH}_{4}$ sampling was always carried out between 09.00 and 11.30 . We removed the gas fluxes measured in 2010 from the data set due to errors in the gas chromatography (GC) analysis and due to long vial storage. To improve GC accuracy a methanizer was installed in late 2010. Further, it was ensured that vial storage time did not exceed 2 weeks in 2011. A detailed description of gas sampling and gas chromatograph settings is given in Eickenscheidt et al. (2014a, b). The $\mathrm{N}_{2} \mathrm{O}$ and $\mathrm{CH}_{4}$ fluxes mentioned as well as soil properties, $\mathrm{N}_{\min }$ values and biomass yield data from the grassland sites are derived from Eickenscheidt et al. (2014b).

For $\mathrm{CO}_{2}$ flux measurements we used the closed dynamic manual chamber system which was described in detail by Drösler (2005) and Elsgaard et al. (2012). The chamber configuration was identical with $\mathrm{N}_{2} \mathrm{O} / \mathrm{CH}_{4}$ chambers as mentioned above. $\mathrm{CO}_{2}$ measurement campaigns took place at irregular time intervals (8-60 days), depending on weather conditions, management activities and the phenological stage of plants (Tables S1-S8 in the Supplement). Measurement campaigns always started $1 \mathrm{~h}$ before sunrise and lasted till late afternoon to cover the full range of the PAR and air and soil temperatures. Opaque and transparent chambers (same dimension as for $\mathrm{N}_{2} \mathrm{O}$ and $\mathrm{CH}_{4}$ measurements) were alternately used at each of the three collars per plot during the time course of a measurement campaign to obtain the ecosystem respiration $\left(R_{\mathrm{ECO}}\right)$ and the net ecosystem exchange (NEE). In total up to $55 \mathrm{NEE}$ measurements and $33 R_{\mathrm{ECO}}$ measurements were conducted per measurement day and plot (Tables S1-S8). As for $\mathrm{N}_{2} \mathrm{O}$ and $\mathrm{CH}_{4}$ measurements, extensions were installed between the collar and chamber in case of vegetation growing higher than the chamber height was (transparent or opaque; volume varied between 309 and $1236 \mathrm{~L})$. Chambers were connected to an infrared gas analyzer (IRGA, LI-820, LI-COR, USA), which continuously determined the $\mathrm{CO}_{2}$ headspace concentration. In the case of extensions being used, chamber air from each level of an extension (every $0.5 \mathrm{~m}$ ) was drawn and merged to guarantee a reliable mixture signal from inside the chamber. Additionally, contrary to chambers used for $\mathrm{N}_{2} \mathrm{O} / \mathrm{CH}_{4}$ measurements, three fans $\left(\mathrm{SUNON}^{\circledR}\right.$ Super Silence MAGLev ${ }^{\circledR}{ }_{-}$ Lüfter) continuously operated during the $\mathrm{CO}_{2}$ measurement to ensure a constant mixing of the chamber air (wind speed in chamber headspace $\sim 1.5-2 \mathrm{~m} \mathrm{~s}^{-1}$ ). Chamber enclosure time was $120 \mathrm{~s}$ for transparent chambers and $240 \mathrm{~s}$ for opaque chambers. The $\mathrm{CO}_{2}$ concentration, air temperature from inside the chamber and site-specific PAR was recorded every $5 \mathrm{~s}$ with a data logger (GP1 Data logger, Delta-T Devices, UK). To prevent heating of the air in the transparent chambers, freezer packs (1-10 pieces) were positioned in the airstream of the fens at the inner surface of the PVC collar (Drösler, 2005; Beetz et al., 2013). Single measurements where the PAR changed by more than $15 \%$ of the starting value or the temperature inside the chamber increased by more than $1.5^{\circ} \mathrm{C}$ compared to the outside air temperature were discarded and the measurement was repeated (LeiberSauheitl et al., 2014). $\mathrm{CO}_{2}$ gas fluxes were calculated by linear regression. Nonsignificant gas fluxes $(P \geq 0.05)$ with slopes close to zero or zero (equilibrium between gross primary production - GPP - and $R_{\mathrm{ECO}}$ ) were not discarded (Alm et al., 2007; Leiber-Sauheitl et al., 2014). For NEE flux calculation, a minimum time interval of $25 \mathrm{~s}$ was used, whereas for $R_{\mathrm{ECO}}$ fluxes a minimum interval of $60 \mathrm{~s}$ was applied.

\subsection{Modeling of $\mathrm{CO}_{2}$ net ecosystem exchange}

The NEE of $\mathrm{CO}_{2}$ is defined as the product of the GPP and the ecosystem respiration $\left(R_{\mathrm{ECO}}\right)$ (Chapin et al., 2006).

$\mathrm{NEE}=\mathrm{GPP}+R_{\mathrm{ECO}}$

In the present study we followed the atmospheric sign convention in which a positive NEE is defined as a net flux of $\mathrm{CO}_{2}$ to the atmosphere (Elsgaard et al., 2012).

\subsubsection{Modeling of ecosystem respiration}

The measured $R_{\mathrm{ECO}}$ fluxes are the sum of autotrophic $\left(R_{\mathrm{a}}\right)$ and heterotrophic $\left(R_{\mathrm{h}}\right)$ respiration. Both $R_{\mathrm{a}}$ and $R_{\mathrm{h}}$ are mainly controlled by temperature (Lloyd and Taylor, 1994; Tjoelker et al., 2001). For each measurement campaign and plot, the dependency between $R_{\mathrm{ECO}}$ and temperature was modeled according to Lloyd and Taylor (1994), who developed an Arrhenius-type relationship to predict soil respiration rates (Eq. 2).

$R_{\mathrm{ECO}}=R_{\mathrm{ref}} \cdot e^{E_{0} \cdot\left(\frac{1}{T_{\mathrm{ref}}-T_{0}}-\frac{1}{T-T_{0}}\right)}$,

where $R_{\mathrm{ECO}}$ is given in milligrams of $\mathrm{CO}_{2}-\mathrm{C} \mathrm{m}^{-2} \mathrm{~h}^{-1}, R_{\mathrm{ref}}$ is the respiration at the reference temperature $\left(\mathrm{mg} \mathrm{CO} \mathrm{CO}_{2}\right.$ $\left.\mathrm{C} \mathrm{m}^{-2} \mathrm{~h}^{-1}\right), E_{0}$ is activation energy $(\mathrm{K}), T_{\text {ref }}$ is the reference temperature $(283.15 \mathrm{~K}), T_{0}$ is the temperature constant for the start of biological processes $(227.13 \mathrm{~K})$, and $T$ is air or soil temperature $(\mathrm{K})$.

In response to the phenological stage of the plants, management activities or changing soil moisture conditions, the applied temperature as an explanatory variable could change during the year. Therefore, the $R_{\mathrm{ECO}}$ model was fitted to the appropriate temperature type (air temperature at $20 \mathrm{~cm}$ or soil temperature at $-2,-5$ or $-10 \mathrm{~cm}$ ) which showed the best explanatory power for $R_{\mathrm{ECO}}$. At the grassland site, we used site-specific climate station temperatures since we assume that they were comparable to plot-specific temperatures due to the comparable management and close proximity. At the A1 plots, $R_{\mathrm{ECO}}$ modeling was based on plot-specific climate station temperature files, whereas at the A2 plots, $R_{\mathrm{ECO}}$ modeling was based on the continuous climate data set of the A1 plots. This procedure probably produced some uncertainty for $R_{\mathrm{ECO}}$ modeling in the $\mathrm{A} 2$ plots, but due to the 
inaccuracy in manually observed temperatures, plot-specific temperature model building would have resulted in a higher uncertainty in these two plots. In the case of the temperature span being too small for model building (e.g., in winter or due to snow cover) or in the case of it not being possible to observe a significant relationship between $R_{\mathrm{ECO}}$ and temperature (e.g., after ploughing), an average $\mathrm{CO}_{2}$ flux was calculated for the measurement campaign. Annual sums of $R_{\mathrm{ECO}}$ were calculated by summing 0.5 hourly $R_{\mathrm{ECO}}$ fluxes recalculated from Eq. (2), based on the linear interpolated parameters $R_{\text {ref }}$ and $E_{0}$ of two consecutive measurement campaigns and the continuous site or plot-specific time series of air and soil temperatures (Elsgaard et al., 2012). In the case of management events (e.g., harvesting and ploughing) or snow cover, $R_{\text {ref }}$ and $E_{0}$ were kept constant from the previous measurement campaign until the management date. After the management, parameters were taken from the subsequent measurement campaign (Leiber-Sauheitl et al., 2013). However, in the case of harvesting at the grassland plots, estimated parameters were linearly interpolated over this period. Estimated parameters and the temperatures used for $R_{\mathrm{ECO}}$ are shown in Tables S1-S8.

\subsubsection{Modeling of gross primary production}

We estimated GPP as the product of measured NEE minus modeled $R_{\mathrm{ECO}}$ at the same time step, since it is not possible to determine GPP through measurements. The relationship between GPP and PAR was modeled by a MichaelisMenten-type rectangular hyperbolic function proposed by Falge et al (2001) (Eq. 3).

$\mathrm{GPP}=\frac{\alpha \cdot \mathrm{PAR}}{\left(1-\left(\frac{\mathrm{PAR}}{2000}\right)+\left(\frac{\alpha \cdot \mathrm{PAR}}{\mathrm{GPP}_{2000}}\right)\right)}$

GPP is given in milligrams of $\mathrm{CO}_{2}-\mathrm{Cm}^{-2} \mathrm{~h}^{-1}, \alpha$ is the initial slope of the curve (light use efficiency; $\mathrm{mg} \mathrm{CO} \mathrm{CO}_{2}$ $\mathrm{C} \mathrm{m}^{-2} \mathrm{~h}^{-1} \mu \mathrm{mol}^{-1} \mathrm{~m}^{-2} \mathrm{~s}^{-1}$ ), the photon flux density of PAR is given in $\mu \mathrm{mol} \mathrm{m}^{-2} \mathrm{~s}^{-1}$, and GPP 2000 is gross primary production at PAR $2000\left(\mathrm{mg} \mathrm{CO} 2-\mathrm{Cm}^{-2} \mathrm{~h}^{-1}\right)$.

Prior to modeling GPP, we corrected the plot-specific PAR values since the acrylic glass of the transparent chambers reflected or absorbed at least $5 \%$ of the incoming radiation (Ps-plastic, Eching, Germany) (Leiber-Sauheitl et al., 2014). Annual sums of GPP were calculated based on the linear interpolation of $\alpha$ and $\mathrm{GPP}_{2000}$ between two consecutive measurement campaigns and the continuous time series of the PAR (Drösler, 2005; Elsgaard et al., 2012). In the case of management events (e.g., harvesting and ploughing), $\alpha$ and $\mathrm{GPP}_{2000}$ were kept constant from the preceding measurement until the management time and were set to zero at the 0.5 hour time step during the working process. Thereafter, parameters were immediately linearly interpolated from the subsequent measurement campaign for the grassland plots. For the arable land plots, parameter interpolation started af- ter the establishment of the seed. Estimated parameters are shown in Tables S1-S8.

\subsubsection{Model evaluation and uncertainties analysis}

For $R_{\mathrm{ECO}}$ and NEE model evaluation, we used Pearson's correlation coefficient $(r)$, Nash-Sutcliffe efficiency (NSE) (Nash and Sutcliffe, 1970), percent bias (PBIAS) and the ratio of the root mean square error to the standard deviation of measured data (RSR) (Moriasi et al., 2007). According to Moriasi et al. (2007), model simulation can be judged satisfactory if NSE $>0.50$ and RSR $\leq 0.70$. For PBIAS, the optimal value is 0.0 , with low-magnitude values indicating accurate model simulation. Additionally, positive PBIAS values indicate model underestimation bias, and negative values indicate model overestimation bias (Gupta et al., 1999; Moriasi et al., 2007). To account for the uncertainties in annual $R_{\mathrm{ECO}}$ and annual GPP modeling, annual sums from the upper and lower limits of the determined parameters $\left(R_{\text {ref }}, E_{0}, \alpha\right.$, $\mathrm{GPP}_{2000}$ ), based on their standard errors (SE) were estimated (Drösler, 2005; Elsgaard et al., 2012). However, quantifying total model uncertainties is challenging because of the multiple sources of errors (Beetz et al., 2013) and due to a lack of independent data for gap-filling verification. The main uncertainty in the present study may derive from management activities where no additional measurements were conducted and parameters were kept constant (e.g., $R_{\text {ref }}$ and $E_{0}$ at the grassland) or set to zero (e.g., $\alpha$ and $\mathrm{GPP}_{2000}$ at the grassland).

\subsection{Estimation of NECB and GWP}

A simple net ecosystem carbon balance (NECB) was calculated for each plot based on the NEE, the carbon export of harvested phytomass, the carbon input through organic fertilizer application and the cumulative annual $\mathrm{CH}_{4}$ exchange (Elsgaard et al., 2012; Beetz et al., 2013).

To assess the global warming potential (GWP) from the different plots, the net emissions of carbon equivalents of NECB and $\mathrm{N}_{2} \mathrm{O}$ were summed according to Beetz et al. (2013). For the conversion of $\mathrm{CH}_{4}$ and $\mathrm{N}_{2} \mathrm{O}$ to $\mathrm{CO}_{2}$ equivalents, radiative forcing factors of 25 and 298 were used (Forster et al., 2007).

\subsection{Statistical analyses}

Statistical analyses were conducted using R 3.0.1 (R Development Core Team, 2013). The assumption of the normality of residuals was tested using the Lilliefors or ShapiroWilk test and by plotting the quantile-quantile plots. The homogeneity of variances in residuals was checked using the Levene or Breusch-Pagan test and by plotting the residuals against the fitted values. Where necessary, data were BoxCox transformed prior to analyses. For the comparison of cumulative modeled GPP, $R_{\mathrm{ECO}}$ and NEE as well as for annual yields and $\mathrm{N}_{\min }$ values, we used a two-factorial ANOVA 
with land use and soil type as fixed effects (including an interaction term in the model), neglecting the individual plotspecific standard error for modeled $\mathrm{CO}_{2}$ values. Nonsignificant terms were removed from the model structure. In the case of significant differences among the means, we used Tukey's honest significant differences test (TukeyHSD). For GW level we used the nonparametric Kruskal-Wallis rank sum test and the nonparametric pairwise Wilcoxon rank sum test with Bonferroni correction for multiple comparisons. In order to test two independent sample means regarding the 2 investigated years 2010 and 2011, we used the Welch two-sample $t$ test $\left(\mathrm{C}_{\text {org }}\right.$ contents, bulk density, yields) or the nonparametric Mann-Whitney $U$ test (for $\mathrm{N}_{\min }$ ). Due to temporal pseudoreplication of time series data $\left(\mathrm{N}_{2} \mathrm{O}, \mathrm{CH}_{4}\right.$ field measurements), we applied linear mixed-effects models (Crawley, 2007; Hahn-Schöfl et al., 2011; Eickenscheidt et al., 2014a, b). For $\mathrm{N}_{2} \mathrm{O}$ fluxes we set up a basic model with land-use type and soil type as fixed effects and the spatial replication (individual plot) nested in time as random effect. We extended the basic model by a variance function due to observed heteroscedasticity. Furthermore, $\mathrm{N}_{2} \mathrm{O}$ fluxes showed significant serial correlation. To take this into account, a first-order temporal autoregressive function was included in the model. Autocorrelation was tested using the Durbin-Watson test and by plotting the empirical autocorrelation structure. The model extension was proved by the Akaike information criterion (AIC). For multiple comparisons we conducted Tukey contrasts using the general linear hypotheses function from the "multcomp" package (Hothorn et al., 2013). $\mathrm{CH}_{4}$ fluxes did not satisfy the necessary requirements for the linear mixed-effects model; therefore, $\mathrm{CH}_{4}$ analysis were restricted to the nonparametric Mann-Whitney $U$ test. We accepted significant differences if $P \leq 0.05$. Results in the text are given as means \pm 1 standard error.

\section{Results}

\subsection{Environmental variables}

Temperatures between the two investigated land-use types and soil types did not differ considerably. In 2010 and 2011, air temperature at a height of $20 \mathrm{~cm}$ ranged from -17.5 to $39.5^{\circ} \mathrm{C}$. Annual mean air temperature at a height of $20 \mathrm{~cm}$ was 7.7 and $8.1^{\circ} \mathrm{C}$ at the $\mathrm{GC}_{\text {medium }}$ and $\mathrm{GC}_{\text {high }}$ sites in 2010 and $8.6^{\circ} \mathrm{C}$ at both grassland sites in 2011 . Soil temperature at a soil depth of $-2 \mathrm{~cm}$ averaged $10.3^{\circ} \mathrm{C}$ at the $\mathrm{GC}_{\text {medium }}$ site and $10.5^{\circ} \mathrm{C}$ at the $\mathrm{GC}_{\text {high }}$ site in 2011 . On the arable land, air temperature at a height of $20 \mathrm{~cm}$ ranged from -15.0 to $39.5^{\circ} \mathrm{C}$ in 2010 and 2011. In 2010 annual mean air temperature at a height of $20 \mathrm{~cm}$ was 8.2 and $8.1^{\circ} \mathrm{C}$ at the $\mathrm{AC}_{\text {medium }}$ and $\mathrm{AC}_{\text {high }}$ sites and 8.8 and $8.7^{\circ} \mathrm{C}$ at the $\mathrm{AC}_{\text {medium }}$ and $\mathrm{AC}_{\text {high }}$ in 2011. Soil temperature at a soil depth of $-2 \mathrm{~cm}$ averaged $10.1^{\circ} \mathrm{C}$ at both arable land sites in 2011 . Longer periods of snow cover occurred from 1 January to 12 March
2010, 28 November 2010 to 10 January 2011 and from 24 January to 5 February 2011 (see also Figs. 4 and 5). In 2011, the annual sum of PAR was $17 \%$ higher than in the year 2010. Annual precipitation amounted to $850 \mathrm{~mm}$ (2010) and $841 \mathrm{~mm} \mathrm{(2011)} \mathrm{in} \mathrm{the} \mathrm{period} \mathrm{investigated,} \mathrm{which} \mathrm{was}$ slightly above the 30-year mean of the period 1981-2010. Mean annual groundwater levels of the $\mathrm{C}_{\text {high }}$ sites were significantly higher (all $P<0.001$ ) than those at the $\mathrm{C}_{\text {medium }}$ sites in 2010 and 2011 (Table 1). Furthermore, the GW level at the arable sites was significantly higher (all $P<0.001$ ) than at the grassland sites in both years investigated. Longer periods of flooding and water saturation were only observed at the $\mathrm{AC}_{\text {high }}$ sites for the period from 1 to 17 June 2010.

\subsection{Soil properties and mineral nitrogen contents}

Total organic carbon contents and bulk density in the 0 $10 \mathrm{~cm}$ and $10-20 \mathrm{~cm}$ soil layers significantly (all $P<0.01$ ) differed between the two soil types investigated (Table 1). At the grassland sites $\mathrm{pH}$ values in the $0-20 \mathrm{~cm}$ soil layer were approximately one unit lower than for the arable land (Table 1). Observed $\mathrm{C} / \mathrm{N}$ ratios at a soil depth of $0-20 \mathrm{~cm}$ were between 10 and 12 (Table 1), indicating nitrogen-rich conditions at all plots. Extractable $\mathrm{N}_{\min }$ contents of the soils ranged from 1 to $178 \mathrm{mg} \mathrm{N} \mathrm{kg}^{-1}$ at the arable sites and from 2 to $115 \mathrm{mg} \mathrm{N} \mathrm{kg}^{-1}$ at the grassland sites (Figs. 2, 3). In both years, the $\mathrm{N}_{\min }$ contents at the grassland sites significantly $(P<0.001)$ exceeded those from the arable site (Fig. 3). Furthermore, the $\mathrm{N}_{\text {min }}$ contents of the $\mathrm{C}_{\text {high }}$ sites were significantly $(P<0.01)$ higher than those of the $\mathrm{C}_{\text {medium }}$ sites (Fig. 3), but this did not apply when the arable land was considered separately. Slightly higher $\mathrm{N}_{\min }$ contents were found at a soil depth of $10-20 \mathrm{~cm}$ than at a soil depth of 0 $10 \mathrm{~cm}$, but differences were only significant for the grassland sites $(P<0.05)$. In both years, $\mathrm{N}_{\min }$ was mainly dominated by $\mathrm{NO}_{3}^{-}$, , whereas $\mathrm{NH}_{4}^{+}$was only of minor importance. However, at the $\mathrm{AC}_{\text {high }}$ sites the proportion of $\mathrm{NO}_{3}^{-}$at a soil depth of $0-10 \mathrm{~cm}$ was lower (approximately $80 \%$ ) than at the $\mathrm{AC}_{\text {medium }}$ sites (approximately $97 \%$ ), whereas at the grassland sites no differences were found between the two soil types investigated (91-95\%).

\subsection{Biomass yield}

The mean annual crop or grass yield ranged from $58 \pm 23$ to $457 \pm 71 \mathrm{~g} \mathrm{C} \mathrm{m}^{-2} \mathrm{yr}^{-1}$ for the arable land and from $297 \pm 32$ to $593 \pm 132 \mathrm{~g} \mathrm{C} \mathrm{m}^{-2} \mathrm{yr}^{-1}$ for the grassland in 2010 and 2011 (see also Eickenscheidt et al., 2014b) (Table 4). For both land-use types, the crop or grass yield was significantly $(P<0.01)$ lower in the year 2010 than in the year $2011(38 \%$ lower at the A sites and $31 \%$ lower at the G sites). However, it has to be taken into consideration that, at the grassland sites, three instead of two cuts were carried out in 2011. On the arable land a longer period with partial flooding and high water saturation damaged or killed some of the maize 
Table 4. Cumulative $R_{\mathrm{ECO}}$, GPP, NEE, $\mathrm{CH}_{4}$ and $\mathrm{N}_{2} \mathrm{O}$ exchange rates as well as $\mathrm{C}$ import through fertilizer and C export due to crop or grass yield.

\begin{tabular}{|c|c|c|c|c|c|c|c|c|}
\hline Plot/year & $\begin{array}{l}\text { cultivated } \\
\text { crop }\end{array}$ & $\begin{array}{l}R_{\mathrm{ECO}} \\
\left(\mathrm{gCm}^{-2} \mathrm{yr}^{-1}\right)\end{array}$ & $\begin{array}{l}\text { GPP } \\
\left(\mathrm{gCm}^{-2} \mathrm{yr}^{-1}\right)\end{array}$ & $\begin{array}{l}\mathrm{NEE} \\
\left(\mathrm{gCm}^{-2} \mathrm{yr}^{-1}\right)\end{array}$ & $\begin{array}{l}\text { Fertilizer } \\
\text { input* } \\
\left(\mathrm{gCm}^{-2} \mathrm{yr}^{-1}\right)\end{array}$ & $\begin{array}{l}\text { Yield* } \\
\left(\mathrm{gCm}^{-2} \mathrm{yr}^{-1}\right)\end{array}$ & $\begin{array}{l}\mathrm{CH}_{4}^{*} \\
\left(\mathrm{gCm}^{-2} \mathrm{yr}^{-1}\right)\end{array}$ & $\begin{array}{l}\mathrm{N}_{2} \mathrm{O}^{*} \\
\left(\mathrm{gNm}^{-2} \mathrm{yr}^{-1}\right)\end{array}$ \\
\hline $\mathrm{A} 1 \mathrm{C}_{\text {medium }} / 10$ & $\begin{array}{l}\text { silage } \\
\text { maize }\end{array}$ & $2473 \pm 272$ & $-1454 \pm 114$ & $1019 \pm 386$ & - & $193 \pm 53$ & - & - \\
\hline $\mathrm{A} 1 \mathrm{C}_{\text {medium }} / 11$ & oat grains & $2992 \pm 230$ & $-1862 \pm 126$ & $1130 \pm 356$ & - & $74 \pm 8$ & $0.51 \pm 0.17$ & $0.27 \pm 0.01$ \\
\hline $\mathrm{A} 1 \mathrm{C}_{\mathrm{high}} / 10$ & $\begin{array}{l}\text { silage } \\
\text { maize }\end{array}$ & $2012 \pm 284$ & $-873 \pm 110$ & $1139 \pm 394$ & - & $58 \pm 23$ & - & - \\
\hline $\mathrm{A} 1 \mathrm{C}_{\mathrm{high}} / 11$ & oat grains & $2117 \pm 123$ & $-1302 \pm 77$ & $815 \pm 200$ & - & $135 \pm 7$ & $0.22 \pm 0.04$ & $0.23 \pm 0.05$ \\
\hline $\mathrm{A} 2 \mathrm{C}_{\text {medium }} / 10$ & $\begin{array}{l}\text { oat grains } \\
+ \text { straw }\end{array}$ & $2704 \pm 544$ & $-1449 \pm 103$ & $1255 \pm 647$ & - & $227 \pm 27$ & - & - \\
\hline $\mathrm{A} 2 \mathrm{C}_{\text {medium }} / 11$ & $\begin{array}{l}\text { maize } \\
\text { grains }\end{array}$ & $2354 \pm 309$ & $-2360 \pm 237$ & $-6 \pm 546$ & - & $457 \pm 71$ & $-0.03 \pm 0.05$ & $0.39 \pm 0.06$ \\
\hline $\mathrm{A} 2 \mathrm{C}_{\text {high }} / 10$ & $\begin{array}{l}\text { oat grains } \\
+ \text { straw }\end{array}$ & $2907 \pm 482$ & $-1200 \pm 137$ & $1707 \pm 619$ & - & $145 \pm 19$ & - & - \\
\hline $\mathrm{A} 2 \mathrm{C}_{\text {high }} / 11$ & $\begin{array}{l}\text { maize } \\
\text { grains }\end{array}$ & $2538 \pm 329$ & $-2188 \pm 253$ & $350 \pm 582$ & - & $330 \pm 79$ & $-0.10 \pm 0.07$ & $0.86 \pm 0.21$ \\
\hline${\mathrm{G} 1 \mathrm{C}_{\text {medium }}} / 10$ & $\begin{array}{l}\text { grass } 2 \\
\text { cuts }\end{array}$ & $3954 \pm 671$ & $-2131 \pm 180$ & $1823 \pm 851$ & 126 & $297 \pm 32$ & - & - \\
\hline $\mathrm{G}_{1 \mathrm{C}_{\text {medium }}} / 11$ & $\begin{array}{l}\text { grass } 3 \\
\text { cuts }\end{array}$ & $4099 \pm 300$ & $-2414 \pm 195$ & $1685 \pm 495$ & 267 & $344 \pm 63$ & $-0.06 \pm 0.09$ & $0.12 \pm 0.01$ \\
\hline $\mathrm{G} 1 \mathrm{C}_{\mathrm{high}} / 10$ & $\begin{array}{l}\text { grass } 2 \\
\text { cuts }\end{array}$ & $3736 \pm 491$ & $-2152 \pm 140$ & $1584 \pm 631$ & 126 & $325 \pm 41$ & - & - \\
\hline $\mathrm{G}_{1} \mathrm{C}_{\mathrm{high}} / 11$ & $\begin{array}{l}\text { grass } 3 \\
\text { cuts }\end{array}$ & $4026 \pm 707$ & $-2633 \pm 138$ & $1393 \pm 845$ & 267 & $455 \pm 41$ & $-0.07 \pm 0.02$ & $0.18 \pm 0.02$ \\
\hline $\mathrm{G} 2 \mathrm{C}_{\text {medium }} / 10$ & $\begin{array}{l}\text { grass } 2 \\
\text { cuts }\end{array}$ & $3683 \pm 453$ & $-2131 \pm 213$ & $1552 \pm 666$ & 76 & $342 \pm 39$ & - & - \\
\hline $\mathrm{G} 2 \mathrm{C}_{\text {medium }} / 11$ & $\begin{array}{l}\text { grass } 3 \\
\text { cuts }\end{array}$ & $4265 \pm 379$ & $-2880 \pm 177$ & $1385 \pm 556$ & 53 & $543 \pm 58$ & $-0.11 \pm 0.05$ & $0.19 \pm 0.02$ \\
\hline $\mathrm{G} 2 \mathrm{C}_{\text {high }} / 10$ & $\begin{array}{l}\text { grass } 2 \\
\text { cuts }\end{array}$ & $3521 \pm 1041$ & $-2093 \pm 152$ & $1428 \pm 1193$ & 76 & $380 \pm 43$ & - & - \\
\hline $\mathrm{G} 2 \mathrm{C}_{\mathrm{high}} / 11$ & $\begin{array}{l}\text { grass } 3 \\
\text { cuts }\end{array}$ & $4316 \pm 562$ & $-2962 \pm 178$ & $1354 \pm 740$ & 53 & $593 \pm 132$ & $-0.02 \pm 0.02$ & $0.31 \pm 0.09$ \\
\hline
\end{tabular}

* Data from grassland plots derived from Eickenscheidt et al. (2014).

A: arable land.

G: grassland.

10: year 2010

11: year 2011 .
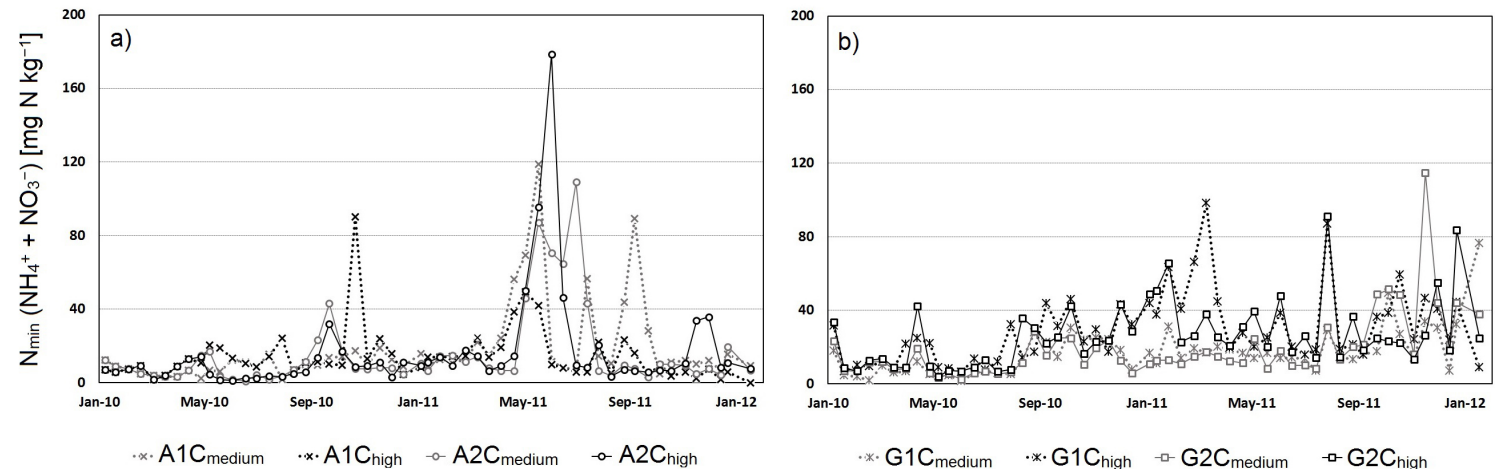

Figure 2. Mineral nitrogen contents $\left(\mathrm{mg} \mathrm{N} \mathrm{kg}^{-1}\right)$ for the arable land (a) and the grassland (b) at a soil depth of $0-10 \mathrm{~cm}$ for the years 2010 and 2011. Data from grassland plots (b) derived from Eickenscheidt et al. (2014b).

seedlings as well as the oat plants in June 2010, especially at the $\mathrm{C}_{\text {high }}$ sites. Furthermore, in 2010 the entire plants were harvested at both arable land sites and used as silo maize or oat corn plus straw, whereas in 2011 only the grains that were grown under both management practices were harvested and the remaining plants were left on the field (Table 3). In both years investigated, the yield from the grassland sites significantly exceeded those from the arable land (all $P<0.001$ ), whereas no significant differences were found between the two soil types observed. 
Table 5. Model evaluation statistics from observed $R_{\mathrm{ECO}}$ vs. modeled $R_{\mathrm{ECO}}$.

\begin{tabular}{|c|c|c|c|c|c|c|c|c|}
\hline \multirow[b]{2}{*}{ Site } & \multicolumn{4}{|c|}{2010} & \multicolumn{4}{|c|}{2011} \\
\hline & $r$ & NSE & PBIAS & RSR & $r$ & NSE & PBIAS & RSR \\
\hline $\mathrm{A} 1 \mathrm{C}_{\text {medium }}$ & 0.90 & 0.70 & -7.93 & 0.55 & 0.98 & 0.95 & -0.17 & 0.22 \\
\hline A $1 C_{\text {high }}$ & 0.98 & 0.96 & 0.44 & 0.19 & 0.98 & 0.97 & 1.79 & 0.18 \\
\hline $\mathrm{A} 2 \mathrm{C}_{\text {medium }}$ & 0.93 & 0.81 & -5.68 & 0.44 & 0.94 & 0.89 & -0.23 & 0.33 \\
\hline A $2 C_{\text {high }}$ & 0.96 & 0.92 & 2.60 & 0.29 & 0.98 & 0.96 & 0.00 & 0.20 \\
\hline $\mathrm{G} 1 \mathrm{C}_{\text {medium }}$ & 0.96 & 0.93 & 1.54 & 0.27 & 0.95 & 0.91 & -2.40 & 0.31 \\
\hline G1C high & 0.89 & 0.75 & -6.27 & 0.50 & 0.97 & 0.95 & 0.03 & 0.23 \\
\hline $\mathrm{G} 2 \mathrm{C}_{\text {medium }}$ & 0.93 & 0.86 & 0.80 & 0.37 & 0.98 & 0.96 & 0.06 & 0.19 \\
\hline G2C & 0.93 & 0.82 & -4.65 & 0.42 & 0.97 & 0.94 & 0.92 & 0.25 \\
\hline
\end{tabular}

$r$ : Pearson's correlation coefficient.

NSE: Nash-Sutcliffe efficiency.

PBIAS: percent bias.

RSR: ratio of the root mean square error to the SD of measured data.

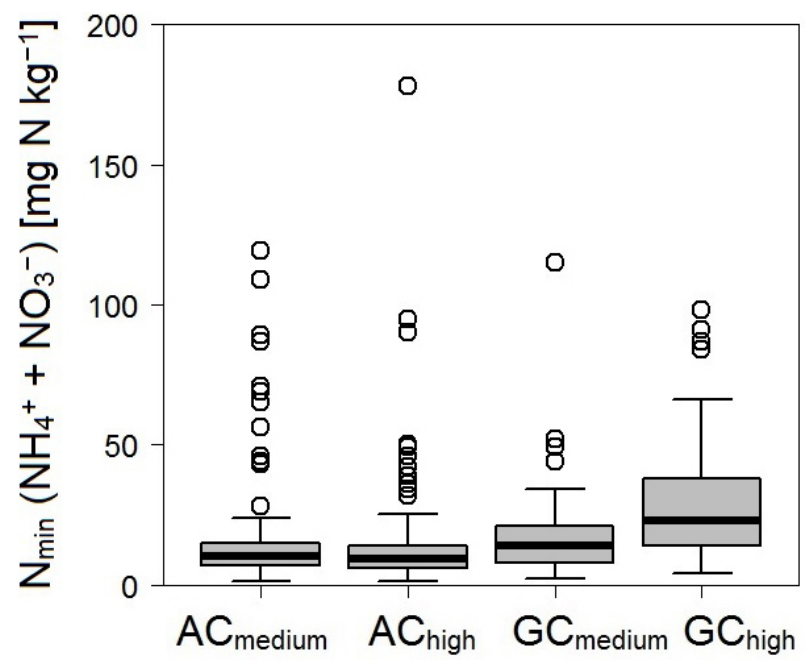

Figure 3. Box plots of mineral nitrogen contents $\left(\mathrm{mg} \mathrm{N} \mathrm{kg}^{-1}\right)$ at a soil depth of $0-10 \mathrm{~cm}$ (A: arable land; G: grassland). Box plot showing median (central thick lines) and 25 and $75 \%$ quartile ranges around the median (box width). Circles present extreme values $(\leq 1.5$ times the interquartile range).

\section{$3.4 \mathrm{CO}_{2}$ fluxes}

The modeling showed that the air temperature in $20 \mathrm{~cm}$ above soil surface and soil temperature at a soil depth of $-2 \mathrm{~cm}$ are the main drivers of $R_{\mathrm{ECO}}$ in the present study, while soil temperatures at soil depths of -5 and $-10 \mathrm{~cm}$ mostly showed distinctly weaker correlations (Tables S1-S8). For the arable land, $88 \%$ of the calculated models based on $T_{\text {air }}$ and only $12 \%$ on $\mathrm{ST}_{2}$, whereas at the grassland sites $54 \%$ of the models were based on $T_{\text {air }}$ and $39 \%$ on $\mathrm{ST}_{2}$. Model evaluation statistics from observed $R_{\mathrm{ECO}}$ versus modeled $R_{\mathrm{ECO}}$ generally revealed a good model performance, with a slight tendency towards model overestimation bias for the year 2010 (mean PBIAS -2.39). Pearson's correlation coefficients for observed $R_{\mathrm{ECO}}$ versus modeled $R_{\mathrm{ECO}}$ ranged between 0.89 and 0.98 , NSE values ranged from 0.70 to 0.97 and RSR values were $\leq 0.55$ (Table 5). According to the annual temperature trend, $R_{\mathrm{ECO}}$ showed a clear seasonality with maximum flux rates during the summer time. In 2010, highest daily $R_{\mathrm{ECO}}$ fluxes of up to $41 \mathrm{~g} \mathrm{CO}_{2}-\mathrm{C} \mathrm{m}^{-2} \mathrm{~d}^{-1}$ were modeled at the $\mathrm{A} 2 \mathrm{C}_{\text {medium }}$ (oat) and $\mathrm{G}_{1} \mathrm{C}_{\text {medium }}$ plot, whereas in 2011, distinctly lower maximum daily $R_{\mathrm{ECO}}$ fluxes of up to 28 and $32 \mathrm{~g} \mathrm{CO}_{2}-\mathrm{C} \mathrm{m}^{-2} \mathrm{~d}^{-1}$ were modeled for the $\mathrm{A} 2 \mathrm{C}_{\text {high }}$ (maize) plot and the $\mathrm{G}_{2} \mathrm{C}_{\text {high }}$ plot, respectively (Figs. 4 and 5). At the grassland sites, annual sums of modeled $R_{\mathrm{ECO}}$ ranged from $3521 \pm 1041\left(\mathrm{G}_{2} \mathrm{C}_{\text {high }} / 10\right)$ to $4316 \pm 562 \mathrm{~g} \mathrm{CO}_{2}-\mathrm{C} \mathrm{m}^{-2} \mathrm{yr}^{-1}\left(\mathrm{G}_{2} \mathrm{C}_{\text {high }} / 11\right)$, which was significantly $(P<0.001)$ higher than at the arable sites where $R_{\mathrm{ECO}}$ ranged from $2012 \pm 284$ ( $\mathrm{A}_{1 C_{\text {high }}} / 10$, maize) to $2992 \pm 230 \mathrm{~g} \mathrm{CO}_{2}-\mathrm{C} \mathrm{m}^{-2} \mathrm{yr}^{-1}$ (A1C $\mathrm{C}_{\text {medium}} / 11$, oat; Table 4, Fig. 6a). Differences in $R_{\mathrm{ECO}}$ between the two soil types investigated were only small and not significantly different (Fig. 6a).

Like $R_{\mathrm{ECO}}$, GPP showed a clear seasonal trend with increasing $\mathrm{CO}_{2}$ uptake capacity, with an increasing PAR intensity in summer time. In 2010, the highest maximum daily GPP of up to $-25 \mathrm{~g} \mathrm{CO}_{2}-\mathrm{C} \mathrm{m}^{-2} \mathrm{~d}^{-1}$ was modeled for the arable land (maize, $\mathrm{C}_{\text {medium }}$ ) and up to $-20 \mathrm{~g} \mathrm{CO}_{2-}$ $\mathrm{C} \mathrm{m}^{-2} \mathrm{~d}^{-1}$ for the grassland ( $\mathrm{G} 2 \mathrm{C}_{\text {high }}$ ), whereas in 2011, distinctly higher GPP values of up to $-35 \mathrm{~g} \mathrm{CO}_{2}-\mathrm{C} \mathrm{m}^{-2} \mathrm{~d}^{-1}$ were modeled for both maize plots and up to $-28 \mathrm{~g} \mathrm{CO}_{2}-$ $\mathrm{C} \mathrm{m}^{-2} \mathrm{~d}^{-1}$ for the $\mathrm{G} 2 \mathrm{C}_{\text {high }}$ plot (Figs. 4 and 5). At the grassland sites annual sums of GPP ranged between -2093 $\pm 152\left(\mathrm{G}_{2} \mathrm{C}_{\mathrm{high}} / 10\right)$ and $-2962 \pm 178 \mathrm{~g} \mathrm{CO}_{2}-\mathrm{C} \mathrm{m}^{-2} \mathrm{yr}^{-1}$ $\left(\mathrm{G}^{2} \mathrm{C}_{\text {high }} / 11\right)$, which was significantly $(P<0.01)$ higher than at the arable sites, where GPP ranged between $-873 \pm 110\left(\mathrm{~A} 1 \mathrm{C}_{\mathrm{high}} / 10\right.$, maize $)$ and $-2360 \pm 237 \mathrm{~g} \mathrm{CO}_{2}-$ $\mathrm{C} \mathrm{m}^{-2} \mathrm{yr}^{-1}$ (A2 $\mathrm{C}_{\text {medium/11, maize; Table 4, Fig. 6b). Differ- }}$ ences in GPP between the two soil types were not significant.

Calculated NEEs were in good agreement with observed NEE. Nevertheless, the calculated percent bias revealed a tendency of model overestimation for both years (mean PBIAS -7.5 in 2010 and -6.1 in 2011). Pearson's corre- 


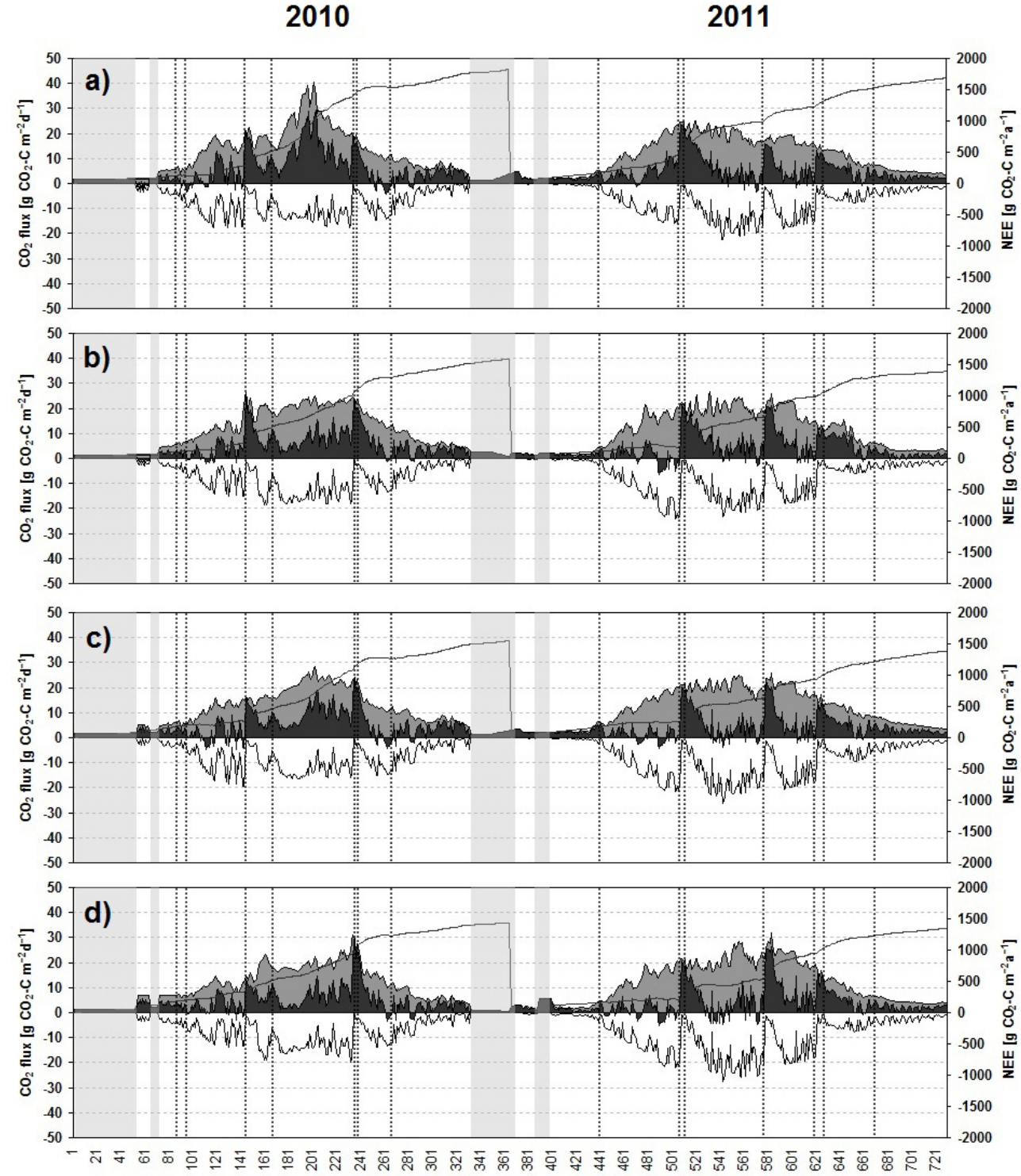

day

$\square$ Reco $\square$ GPP $\quad$ NEE Cumulative NEE

Figure 4. Time series of modeled $\mathrm{CO}_{2}$ fluxes $\left(\mathrm{g} \mathrm{CO}_{2}-\mathrm{C} \mathrm{m}^{-2} \mathrm{~d}^{-1}\right)$ and cumulative $\mathrm{NEE}\left(\mathrm{g} \mathrm{CO}_{2}-\mathrm{C} \mathrm{m}^{-2} \mathrm{yr}^{-1}\right)$ for each site in 2010 and 2011: (a) grassland, cattle slurry, $\mathrm{C}_{\text {medium }}$; (b) grassland cattle slurry, $\mathrm{C}_{\mathrm{high}}$; (c) grassland biogas digestate $\mathrm{C}_{\text {medium }}$; (d) grassland, biogas digestate, $\mathrm{C}_{\mathrm{high}}$. Grey bars mark the period with snow cover. Dashed lines indicate management activities (see Table 3 ).

lation coefficients for observed NEE versus calculated NEE ranged from 0.79 to 0.98 , NSE values ranged from 0.61 to 0.96 (Table 6). The mean RSR value was 0.36. Annual NEE differed significantly $(P<0.01)$ between the two landuse types with lower NEE values at the arable sites, ranging from $-6 \pm 546\left(\mathrm{~A} 2 \mathrm{C}_{\text {medium }} / 11\right.$, maize $)$ to $1707 \pm 619 \mathrm{~g}$ $\mathrm{CO}_{2}-\mathrm{C} \mathrm{m}^{-2} \mathrm{yr}^{-1}\left(\mathrm{~A} 2 \mathrm{C}_{\text {high }} / 10\right.$, oat $)$, than at the grassland sites, where NEE ranged from $1354 \pm 740\left(\mathrm{G} 2 \mathrm{C}_{\text {high }} / 11\right)$ to $1823 \pm 851 \mathrm{~g} \mathrm{CO}_{2}-\mathrm{C} \mathrm{m}^{-2} \mathrm{yr}^{-1}\left(\mathrm{G}_{1} \mathrm{C}_{\text {medium }} / 10\right.$; Table 4 , Fig. 6c). Differences between the two soil types were not significant for NEE.

\section{5 $\quad \mathrm{N}_{2} \mathrm{O}$ and $\mathrm{CH}_{4}$ fluxes}

Nitrous oxide emissions were generally low at all plots (Fig. 7). $\mathrm{N}_{2} \mathrm{O}$ fluxes rarely exceeded $50 \mu \mathrm{g} \mathrm{N} \mathrm{m}{ }^{-2} \mathrm{~h}^{-1}$. However, single $\mathrm{N}_{2} \mathrm{O}$ peaks with maximum flux rates of up to $2832 \mu \mathrm{g} \mathrm{N} \mathrm{m}^{-2} \mathrm{~h}^{-1}$ were detected on 3 June at both maize plots as well as on 6 September at both oat plots with maximum flux rates of up to $289 \mu \mathrm{g} \mathrm{N} \mathrm{m}{ }^{-2} \mathrm{~h}^{-1}$. At the grassland sites, highest $\mathrm{N}_{2} \mathrm{O}$ fluxes of up to $992 \mu \mathrm{g} \mathrm{N} \mathrm{m}{ }^{-2} \mathrm{~h}^{-1}$ were found immediately after fertilizer application (see Eickenscheidt et al., 2014b). In general, $\mathrm{N}_{2} \mathrm{O}$ fluxes from the arable 


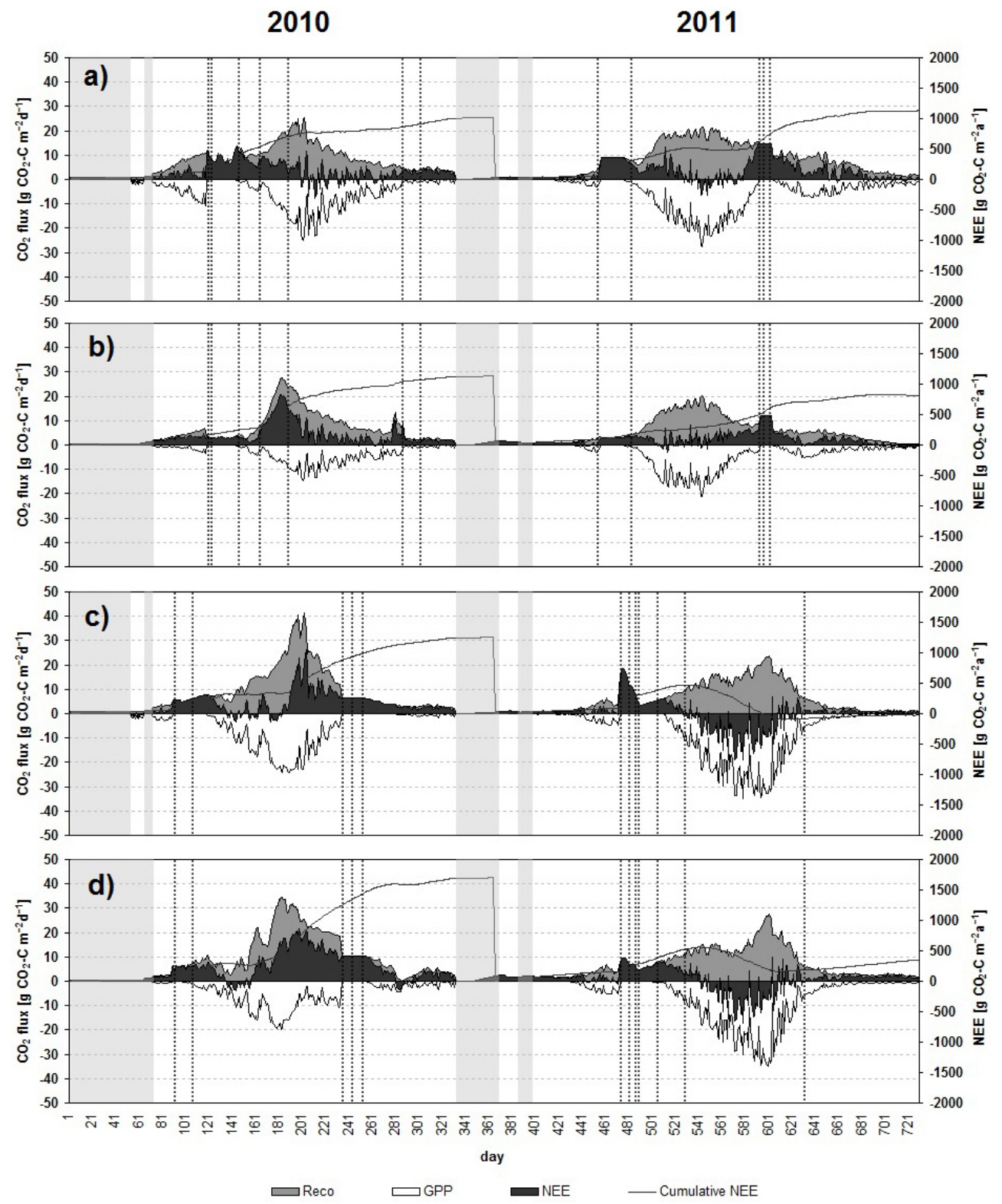

Figure 5. Time series of modeled $\mathrm{CO}_{2}$ fluxes $\left(\mathrm{g} \mathrm{CO}_{2}-\mathrm{C} \mathrm{m}^{-2} \mathrm{~d}^{-1}\right)$ and cumulative $\mathrm{NEE}\left(\mathrm{g} \mathrm{CO}_{2}-\mathrm{C} \mathrm{m}^{-2} \mathrm{yr}^{-1}\right)$ for each site in 2010 and 2011 : (a) arable land, 2010 maize, 2011 oat, $\mathrm{C}_{\text {medium }}$; (b) arable land, 2010 maize, 2011 oat, $\mathrm{C}_{\text {high }}$; (c) arable land, 2010 oat, 2011 maize, $\mathrm{C}_{\text {medium }}$; (d) arable land, 2010 oat, 2011 maize, $\mathrm{C}_{\text {high. }}$ Grey bars mark the period with snow cover. Dashed lines indicate management activities (see Table 3).

sites were significantly $(P<0.01)$ higher than at the grassland sites (Fig. 8a). Furthermore, $\mathrm{N}_{2} \mathrm{O}$ fluxes from the $\mathrm{C}_{\text {high }}$ sites significantly $(P<0.05)$ exceeded $\mathrm{N}_{2} \mathrm{O}$ fluxes from the $\mathrm{C}_{\text {medium }}$ sites, but this did not apply when the arable land was considered separately (Table 4). Significant differences within the land-use types, regarding $\mathrm{N}_{2} \mathrm{O}$ flux rates, were only found between the grassland plots, where the application of biogas digestate significantly $(P<0.01)$ enhanced the $\mathrm{N}_{2} \mathrm{O}$ fluxes compared to the application of cattle slurry (see Eickenscheidt et al., 2014b). For the arable land dis- tinctly different $\mathrm{N}_{2} \mathrm{O}$ flux rates between maize and oat were not found, but the single peak emissions observed led to significantly $(P<0.01)$ higher annual cumulative $\mathrm{N}_{2} \mathrm{O}$ emissions at the maize plots (Table 4, Fig. 8 a). $\mathrm{N}_{2} \mathrm{O}$ peaks accounted for 75 and $87 \%$ of the annual $\mathrm{N}_{2} \mathrm{O}$ balances at the maize plots, whereas at the oat plots peaks account for 63 and $54 \%$ of the annual $\mathrm{N}_{2} \mathrm{O}$ sums (at $\mathrm{C}_{\text {medium }}$ and $\mathrm{C}_{\text {high }}$, respectively). Annual cumulative $\mathrm{N}_{2} \mathrm{O}$ emissions ranged from $0.12 \pm 0.01 \mathrm{~g} \mathrm{~N} \mathrm{~m}^{-2} \mathrm{yr}^{-1}\left(\mathrm{G}_{1} \mathrm{C}_{\text {medium }}\right)$ to $0.86 \pm 0.21 \mathrm{~g}$ $\mathrm{N} \mathrm{m}^{-2} \mathrm{yr}^{-1}$ (A2 $\mathrm{C}_{\text {high }}$, maize; Table 4). 
Table 6. Model evaluation statistics from observed NEE vs. modeled NEE.

\begin{tabular}{|c|c|c|c|c|c|c|c|c|}
\hline \multirow[b]{2}{*}{ Site } & \multicolumn{4}{|c|}{2010} & \multicolumn{4}{|c|}{2011} \\
\hline & $r$ & NSE & PBIAS & RSR & $r$ & NSE & PBIAS & RSR \\
\hline $\mathrm{A} 1 \mathrm{C}_{\text {medium }}$ & 0.94 & 0.87 & -11.84 & 0.36 & 0.97 & 0.93 & 1.41 & 0.26 \\
\hline $\mathrm{A} 1 \mathrm{C}_{\mathrm{high}}$ & 0.94 & 0.88 & -7.94 & 0.35 & 0.98 & 0.96 & -4.94 & 0.21 \\
\hline $\mathrm{A} 2 \mathrm{C}_{\text {medium }}$ & 0.85 & 0.72 & 3.03 & 0.53 & 0.96 & 0.92 & -3.64 & 0.28 \\
\hline A $2 C_{\text {high }}$ & 0.79 & 0.61 & 3.63 & 0.63 & 0.96 & 0.91 & -9.56 & 0.29 \\
\hline $\mathrm{G}_{1 \mathrm{C}_{\text {medium }}}$ & 0.90 & 0.80 & -10.98 & 0.45 & 0.92 & 0.84 & -10.47 & 0.40 \\
\hline $\mathrm{G} \mathrm{C}_{\mathrm{high}}$ & 0.91 & 0.82 & -12.07 & 0.43 & 0.94 & 0.88 & -10.04 & 0.35 \\
\hline $\mathrm{G} 2 \mathrm{C}_{\text {medium }}$ & 0.95 & 0.89 & -13.23 & 0.33 & 0.96 & 0.92 & -5.43 & 0.28 \\
\hline G2 $C_{\text {high }}$ & 0.94 & 0.87 & -10.71 & 0.36 & 0.94 & 0.89 & -6.22 & 0.34 \\
\hline
\end{tabular}

$r$ : Pearson's correlation coefficient.

NSE: Nash-Sutcliffe efficiency.

PBIAS: percent bias.

RSR: ratio of the root mean square error to the SD of measured data.

Table 7. Estimated global warming potential for a time horizon of 100 years.

\begin{tabular}{|c|c|c|c|c|}
\hline Site/period & $\begin{array}{l}\mathrm{GWP}_{100} \mathrm{NEE}_{\text {corrected }}{ }^{*} \\
\left(\mathrm{gCO}_{2} \text { eq. } \mathrm{m}^{-2} \mathrm{yr}^{-1}\right)\end{array}$ & $\begin{array}{l}\mathrm{GWP}_{100} \mathrm{CH}_{4} \\
\left(\mathrm{gCO}_{2} \text { eq. } \mathrm{m}^{-2} \mathrm{yr}^{-1}\right)\end{array}$ & $\begin{array}{l}\mathrm{GWP}_{100} \mathrm{~N}_{2} \mathrm{O} \\
\left(\mathrm{gCO}_{2} \text { eq. }\right. \\
\left.\mathrm{m}^{-2} \mathrm{yr}^{-1}\right)\end{array}$ & $\begin{array}{l}\mathrm{GWP}_{100} \text { balance } \\
{\left[\mathrm{gCO}_{2} \text { eq. } \mathrm{m}^{-2} \mathrm{yr}^{-1}\right]}\end{array}$ \\
\hline $\mathrm{A} 1 \mathrm{C}_{\text {medium }} / 11$ & $4419 \pm 1336$ & $16.96 \pm 5.65$ & $126.32 \pm 4.68$ & $4562 \pm 1346$ \\
\hline $\mathrm{A} 1 \mathrm{C}_{\mathrm{high}} / 11$ & $3487 \pm 760$ & $7.32 \pm 1.33$ & $107.61 \pm 23.39$ & $3601 \pm 785$ \\
\hline $\mathrm{A} 2 \mathrm{C}_{\text {medium }} / 11$ & $1655 \pm 2264$ & $-1.00 \pm 1.33$ & $182.47 \pm 28.07$ & $1837 \pm 2293$ \\
\hline $\mathrm{A} 2 \mathrm{C}_{\mathrm{high}} / 11$ & $2496 \pm 2426$ & $-3.33 \pm 1.66$ & $402.36 \pm 98.25$ & $2895 \pm 2526$ \\
\hline $\mathrm{G} 1 \mathrm{C}_{\text {medium }} / 11$ & $6467 \pm 2048$ & $-2.00 \pm 2.99$ & $56.14 \pm 4.68$ & $6521 \pm 2056$ \\
\hline $\mathrm{G}_{1} \mathrm{C}_{\mathrm{high}} / 11$ & $5802 \pm 3252$ & $-2.33 \pm 0.67$ & $84.21 \pm 9.36$ & $5884 \pm 3262$ \\
\hline $\mathrm{G} 2 \mathrm{C}_{\text {medium }} / 11$ & $6881 \pm 2253$ & $-3.66 \pm 1.66$ & $88.89 \pm 9.36$ & $6967 \pm 2264$ \\
\hline $\mathrm{G} 2 \mathrm{C}_{\mathrm{high}} / 11$ & $6951 \pm 3200$ & $-0.67 \pm 0.67$ & $145.04 \pm 42.11$ & $7095 \pm 3243$ \\
\hline
\end{tabular}

* Corrected for $\mathrm{C}$ export and $\mathrm{C}$ import.

Most of the time, all sites showed a weak uptake of $\mathrm{CH}_{4}$ or zero fluxes. $\mathrm{CH}_{4}$ peaks up to $173 \mu \mathrm{g} \mathrm{C} \mathrm{m}{ }^{-2} \mathrm{~h}^{-1}$ were occasionally found immediately after fertilization at the G1 sites (see Eickenscheidt et al., 2014b). Moreover, a high $\mathrm{CH}_{4}$ peak event of up to $2177 \mu \mathrm{g} \mathrm{C} \mathrm{m}{ }^{-2} \mathrm{~h}^{-1}$ occurred on 14 July 2011 at the oat plots. Generally, $\mathrm{CH}_{4}$ fluxes of the arable sites significantly $(P<0.01)$ exceeded $\mathrm{CH}_{4}$ fluxes of the grassland sites, whereas no differences were found between the two soil types investigated (Figs. 7 and 8b). Significantly different $\mathrm{CH}_{4}$ fluxes within the land-use types could not be observed regarding the annual fluxes in 2011. However, considering the annual cumulative exchange rates, $\mathrm{CH}_{4}$ emissions of the oat plots significantly $(P<0.05)$ exceeded those of the maize plots. The observed weak $\mathrm{CH}_{4}$ emissions or uptakes amounted to cumulative annual $\mathrm{CH}_{4}$ exchange rates ranging between $-0.11 \pm 0.05 \mathrm{~g} \mathrm{C} \mathrm{m}^{-2} \mathrm{yr}^{-1}$ (G2C $\left.\mathrm{C}_{\text {medium }}\right)$ and $0.51 \pm 0.17 \mathrm{~g} \mathrm{C} \mathrm{m}^{-2} \mathrm{yr}^{-1}$ (A1C $\mathrm{C}_{\text {medium }}$, oat; Table 4). However, as previously mentioned for $\mathrm{N}_{2} \mathrm{O}$, the single $\mathrm{CH}_{4}$ peak event observed at the arable sites determines the cumulative sum of $\mathrm{CH}_{4}$ and turns the plots from a sink into a source of $\mathrm{CH}_{4}$.

\subsection{NECB and GWP}

Taking into consideration the $\mathrm{C}$ export from harvested phytomass, $\mathrm{C}$ import from fertilization, and $\mathrm{CH}_{4}-\mathrm{C}$ and $\mathrm{CO}_{2}-\mathrm{C}$ exchange (NEE), calculated NECB ranged from $451 \pm 617$ (A2 $\mathrm{C}_{\text {medium }}$, maize) to $1894 \pm 872 \mathrm{~g} \mathrm{C} \mathrm{m}^{-2} \mathrm{yr}^{-1}$ (G2C $\mathrm{C}_{\text {high }}$ ). Estimated GWPs ranged from $1837 \pm 2293$ (A2C $\mathrm{C}_{\text {medium }}$, maize) to $7095 \pm 3243 \mathrm{~g} \mathrm{CO}_{2 \text { eq. }} \mathrm{m}^{-2} \mathrm{yr}^{-1}\left(\mathrm{G}_{2} \mathrm{C}_{\text {high }}\right)$, revealing a very high release of greenhouse gases from all plots (Table 7). However, $\mathrm{CO}_{2}$ dominated the GWP of all plot by nearly $100 \%$ (ranging between 97 and $99 \%$ and, for maize, between 86 and $90 \%$ ), whereas the contributions of $\mathrm{N}_{2} \mathrm{O}$ and $\mathrm{CH}_{4}$ were almost negligible, with the exception of the maize plots.

\section{Discussion}

\subsection{Magnitude of GHG fluxes}

The observed annual $\mathrm{CO}_{2}$ emissions were in the upper range or sometimes higher than $\mathrm{CO}_{2}$ exchange rates reported in 

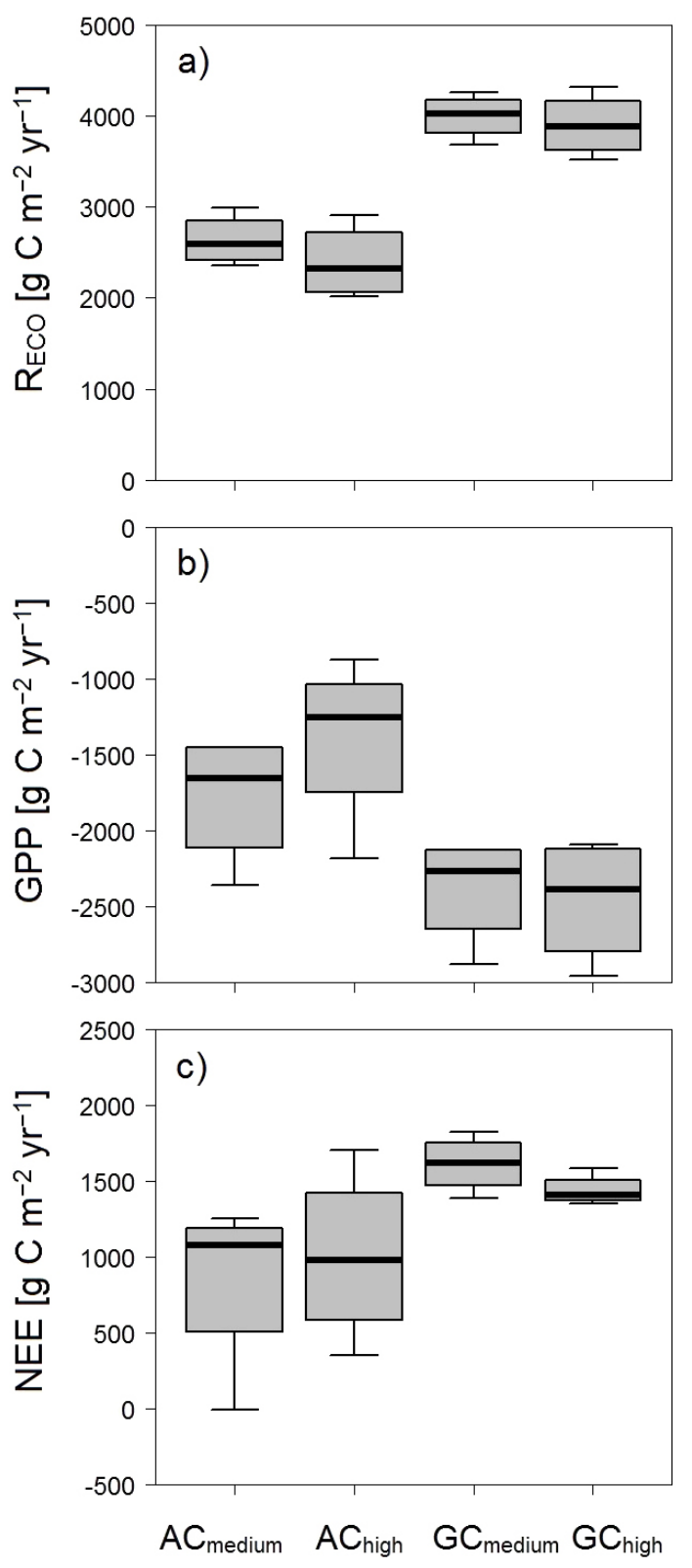

Figure 6. Box plots of cumulative $R_{\mathrm{ECO}}(\mathbf{a})$, GPP (b) and NEE (c) for the two soil types and land-use types. Box plot showing median (central thick lines) and 25 and $75 \%$ quartile ranges around the median (box width).

the literature from temperate or boreal drained arable lands (e.g., Maljanen et al., 2001, 2007, 2010; Grønlund et al., 2008; Höper et al., 2008; Leifeld et al., 2011; Elsgaard et al., 2012; Drösler et al., 2013) and grasslands (e.g., Maljanen et al., 2001; Grønlund et al., 2006, 2008; Maljanen et al., 2010; Elsgaard et al., 2012; Beetz et al., 2013; Drösler et al., 2013; Leifeld et al., 2014; Renou-Wilson et al., 2014). No differences in the $\mathrm{CO}_{2}$ release of the $\mathrm{C}_{\text {medium }}$ and $\mathrm{C}_{\text {high }}$ sites were found in the current study, and no information about $\mathrm{CO}_{2}$ fluxes of soils comparable to those of the $\mathrm{C}_{\text {medium }}$ sites were available in the literature. Observed $\mathrm{CO}_{2}$ emissions from the arable land were in the range of or in some cases double (4.51-12.04 $\mathrm{t} \mathrm{CO}_{2}-\mathrm{C} \mathrm{ha} \mathrm{yr}^{-1}$ ) the IPCC default emission factor from the Tier 1 approach for drained boreal and temperate arable lands (7.9 $\mathrm{t} \mathrm{CO}_{2}-\mathrm{Cha} \mathrm{yr}^{-1}$; IPCC, 2014), whereas $\mathrm{CO}_{2}$ emissions observed at the grassland sites were more than 3 times higher $\left(15.81-18.94 \mathrm{t} \mathrm{CO}_{2}-\mathrm{C} \mathrm{ha} \mathrm{yr}^{-1}\right.$ ) than the IPCC default emission factor for deeply drained temperate grasslands (6.1 $\mathrm{t} \mathrm{CO}_{2}-\mathrm{C} \mathrm{ha} \mathrm{yr}^{-1}$; IPCC, 2014). However, comparison of $\mathrm{CO}_{2}$ exchange rates is difficult since annual variability is very high. For example, Leifeld et al. (2014) reported that the NECB of a temperate grassland in Germany ranged from 0.98 to $19.46 \mathrm{t} \mathrm{Cha}^{-1} \mathrm{yr}^{-1}$, with a 5-year mean of $9.06 \pm 6.64 \mathrm{t} \mathrm{Cha}^{-1} \mathrm{yr}^{-1}$. In this study the highest value was observed for the period 2010 to 2011, which was in good agreement with the values estimated by us during this period. The finding is also in line with KasimirKlemendtsson et al. (1997), who reported net $\mathrm{CO}_{2}$ exchange rates ranging from 8 to $115 \mathrm{t} \mathrm{CO}_{2} \mathrm{ha}^{-1} \mathrm{yr}^{-1}$ for farmed organic soils, demonstrating the high bandwidth of measured $\mathrm{CO}_{2}$ balances.

Observed cumulative annual $\mathrm{N}_{2} \mathrm{O}$ emissions were distinctly lower than the default emission factor from the Tier 1 approach for boreal and temperate, drained arable land (13 kg $\mathrm{N}_{2} \mathrm{O}-\mathrm{N} \mathrm{ha}^{-1} \mathrm{yr}^{-1}$; IPCC. 2014) and for temperate deeply drained, nutrient-rich grassland $\left(8.2 \mathrm{~kg} \mathrm{~N}_{2} \mathrm{O}-\mathrm{N} \mathrm{ha}^{-1} \mathrm{yr}^{-1}\right.$; IPCC, 2014). In line with this, several other authors reported much higher $\mathrm{N}_{2} \mathrm{O}$ emissions from organic soils ranging from 0 to $61 \mathrm{~kg} \mathrm{~N}_{2} \mathrm{O}-\mathrm{N} \mathrm{ha}^{-1} \mathrm{yr}^{-1}$ for arable lands (KasimirKlemendtsson et al., 1997; Augustin et al., 1998; Flessa et al., 1998; Petersen et al., 2012; Drösler et al., 2013) and ranging from 1.15 to $41 \mathrm{~kg} \mathrm{~N}_{2} \mathrm{O}-\mathrm{N} \mathrm{ha}^{-1} \mathrm{yr}^{-1}$ for grasslands (Velthof et al., 1996; Augustin et al., 1998; Flessa et al., 1997 and 1998; van Beek et al., 2010, 2011; Kroon et al., 2010; Petersen et al., 2012; Beetz et al., 2013; Drösler et al., 2013).

As expected, observed $\mathrm{CH}_{4}$ fluxes from all plots were low, which is in line with generally low groundwater levels and the absence of aerenchymous plant species which can transport $\mathrm{CH}_{4}$ from an anaerobic layer to the atmosphere, bypassing the oxic zone at the soil surface (Grosse et al., 1992; Svensson and Sundh, 1992; Whalen, 2005). Cumulative annual $\mathrm{CH}_{4}$ emissions or uptakes were in the range reported for other deeply drained arable lands and grasslands (Maljanen et al., 2010; Petersen et al., 2012; Beetz et al., 2013; Drösler et al., 2013; Renou-Wilson et al., 2014) and also fit in well with the IPCC default emission factor for boreal and temperate drained arable land $\left(0 \mathrm{~kg} \mathrm{CH}_{4} \mathrm{ha}^{-1} \mathrm{yr}^{-1}\right.$; IPCC, 2014). However, the IPCC gives an emission factor for a temperate deeply drained, nutrient-rich grassland $(16 \mathrm{~kg}$ $\mathrm{CH}_{4} \mathrm{ha}^{-1} \mathrm{yr}^{-1}$; IPCC, 2014) that is distinctly higher than our estimations. 

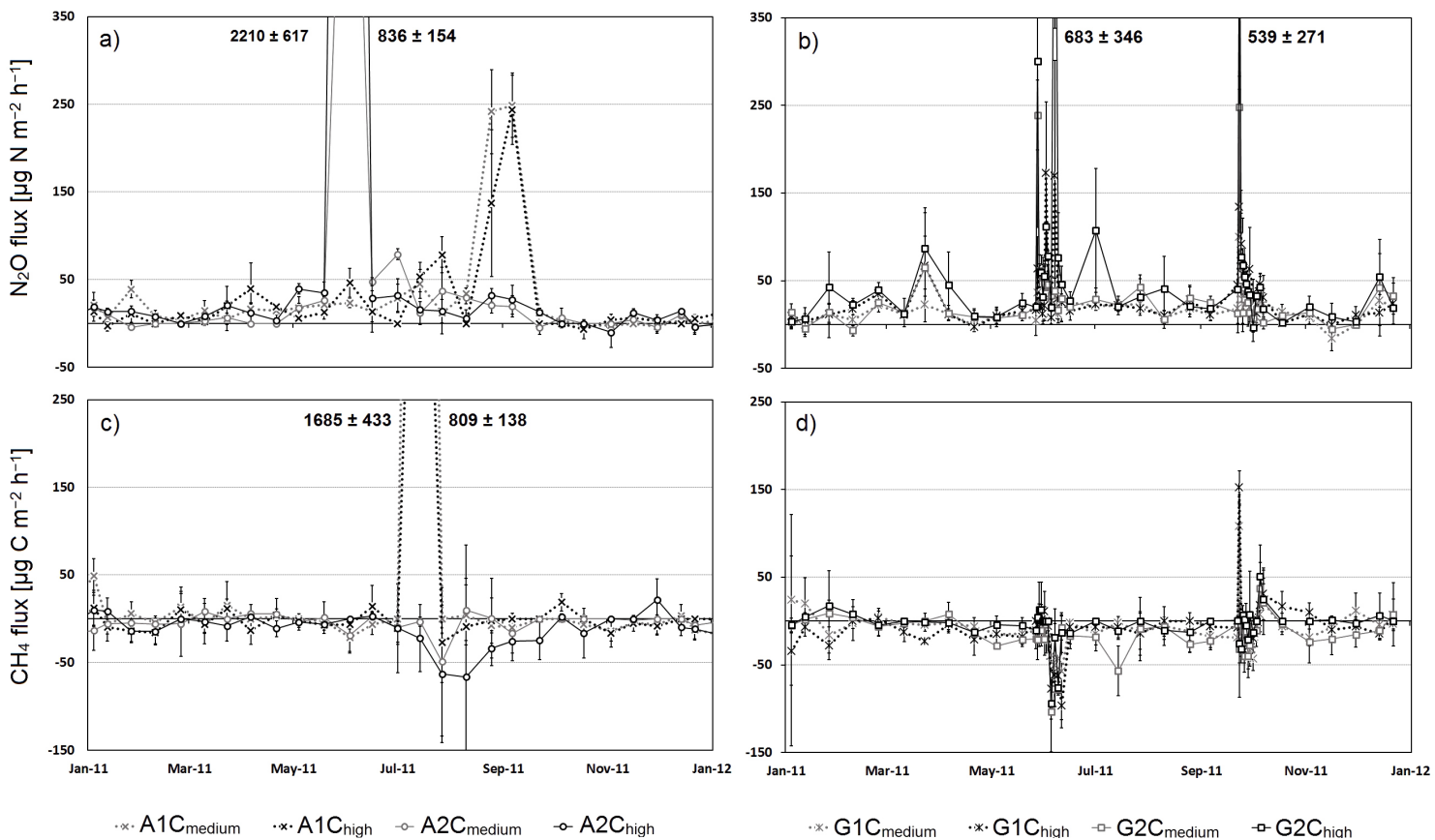

Figure 7. Time series of measured $\mathrm{N}_{2} \mathrm{O}$ fluxes (a: arable land; b: grassland) and $\mathrm{CH}_{4}$ fluxes (c: arable land; d: grassland) for the year 2011 . Data from grassland plots (b, c) derived from Eickenscheidt et al. (2014b).
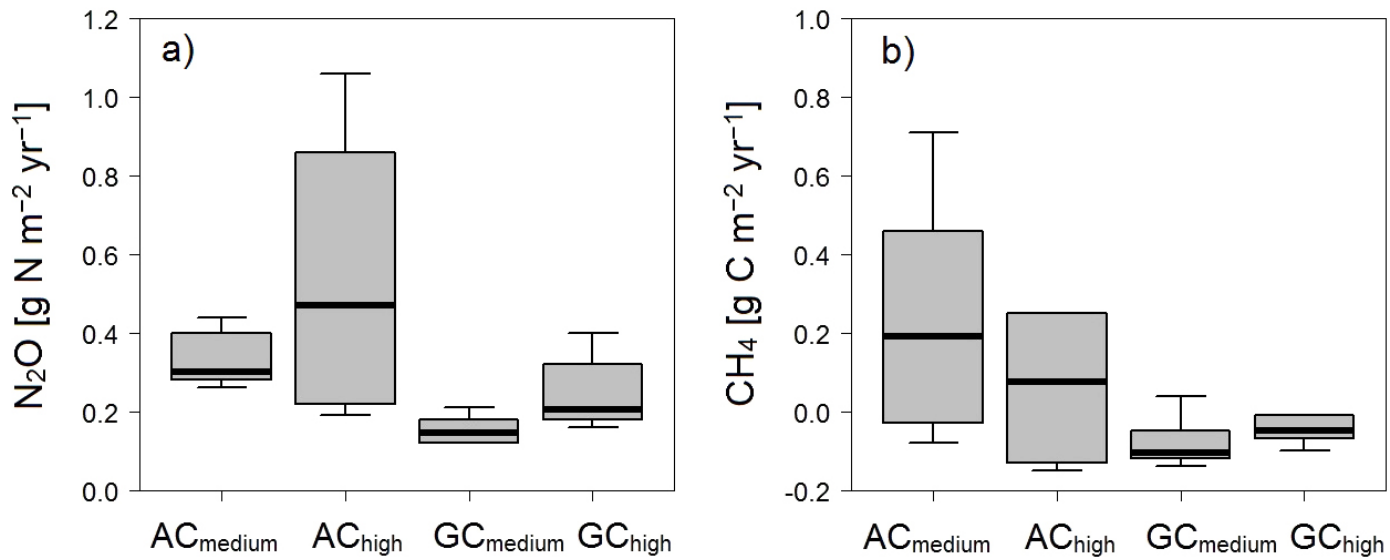

Figure 8. Box plots of cumulative annual $\mathrm{N}_{2} \mathrm{O}$ emissions (a) and cumulative annual $\mathrm{CH}_{4}$ emissions (b) for the two soil types and land-use types. Box plot showing median (central thick lines) and 25 and $75 \%$ quartile ranges around the median (box width).

\subsection{Uncertainties in GHG fluxes and modeling}

Several factors probably influenced the accuracy of estimated $\mathrm{CO}_{2}$ exchange rates. Firstly, the infrared gas analyzer used, LI-820, is just able to measure $\mathrm{CO}_{2}$ concentrations, without considering spectral cross-sensitivity due to absorption band broadening and inherent instrument cross-sensitivity. Both cause an overestimation of the $\mathrm{CO}_{2}$ mole fraction in samples containing water vapor. Furthermore, the dilution effect of $\mathrm{CO}_{2}$ in $\mathrm{H}_{2} \mathrm{O}$ can cause a proportionate decrease in the sample $\mathrm{CO}_{2}$ concentration. In particular, the increase in water vapor due to evaporation and/or transpiration leads to the fact that carbon uptake will be overestimated, whereas the carbon release will respond vice versa (see application note no. 129 from LI-COR). This is in line with Pérez-Priego et al. (2015), who found that the increase in water vapor concentration in the headspace leads to one of the most important systematic errors affecting $\mathrm{CO}_{2}$ flux estimations when using closed chambers provided that no corresponding correction is performed. According to Welles et al. (2001), the largest error due to increasing water vapor and the dilution effect will occur on wet soils with low $\mathrm{CO}_{2}$ fluxes $\left(\mathrm{d} c / \mathrm{d} t<1 \mathrm{ppm} \mathrm{s}^{-1}\right)$ and dry, sunny, conditions, when chamber air temperature and water vapor can rise rapidly. Only in advective high- 
flux situations when the rate of increasing water vapor is less than $1 \%$ of the rate of increasing chamber $\mathrm{CO}_{2}$ may dilution effects be ignored. This finding was also confirmed by Matsuura et al. (2011). However, neither corrections for cross-sensitivity and band broadening nor a dilution correction were applied in the present study. Nevertheless, the cooling system used partially reduced the dilution effect by ensuring a more or less constant air temperature and additionally by affecting air moisture and $\mathrm{H}_{2} \mathrm{O}$ condensation, albeit to an unknown extent. However, it must be pointed out that modeled GPP will possibly be overestimated, whereas modeled $R_{\mathrm{ECO}}$ will possibly be underestimated, resulting in significantly higher calculated NEE values. For future ecosystem $\mathrm{CO}_{2}$-exchange studies we strongly recommend the use of a different infrared gas analyzer or the concurrent measurement of the relative humidity and temperature to perform a dilution correction to reduce significant errors in $\mathrm{CO}_{2}$ flux measurements as proposed by Welles et al. (2001) and PérezPriego et al. (2015).

Secondly the $R_{\mathrm{ECO}}$ models based only on temperature changes disregarding the effect of soil moisture or GW level. Thus, changing soil moisture contents or GW levels between two consecutive measurements campaigns were neglected since we assume a linear change in derived model parameters (see also Beetz et al., 2013; Leiber-Sauheitl et al., 2014). Thirdly, some uncertainty in $R_{\mathrm{ECO}}$ models occurred at both A2 plots since no plot-specific temperature models were used. Due to the inaccuracy of the manually determined temperatures, we decided not to model plot-specific temperatures for both A2 plots. However, we assume that the use of air temperatures from climate stations of the adjacent arable plots is less problematic for $R_{\mathrm{ECO}}$ modeling since $88 \%$ of $R_{\mathrm{ECO}}$ models were fitted to the air temperature, which is considered to be comparable between the two different plots. Fourthly, management activities such as ploughing at the arable sites probably produced peak $\mathrm{CO}_{2}$ emissions, which we may have missed. Additionally, it can be assumed that after harvesting at the grassland sites, $R_{\mathrm{ECO}}$ decreased due to the reduced phytomass. However, additional measurement campaigns to capture this effect did not take place in the current study and no corresponding data were found in the literature. Furthermore, it is well known that the application of organic fertilizers produced short-term $\mathrm{CO}_{2}$ emission peaks, which were also not sufficiently detected. However, both sources of errors may even have an opposite effect. Fifthly, for GPP, the linear interpolation of parameters produced some uncertainties since it can be assumed that plant growth after cutting did not increase linearly (Horrocks and Valentine, 1999; Beetz et al., 2013). However, with the available data set, it was not possible to quantify the error by the used interpolation approach of parameters since the data set was too small for cross validation and no additional measurements for an independent model validation were conducted. In addition, despite high model accuracy, the calculated PBIAS revealed a slight model overestimation bias for

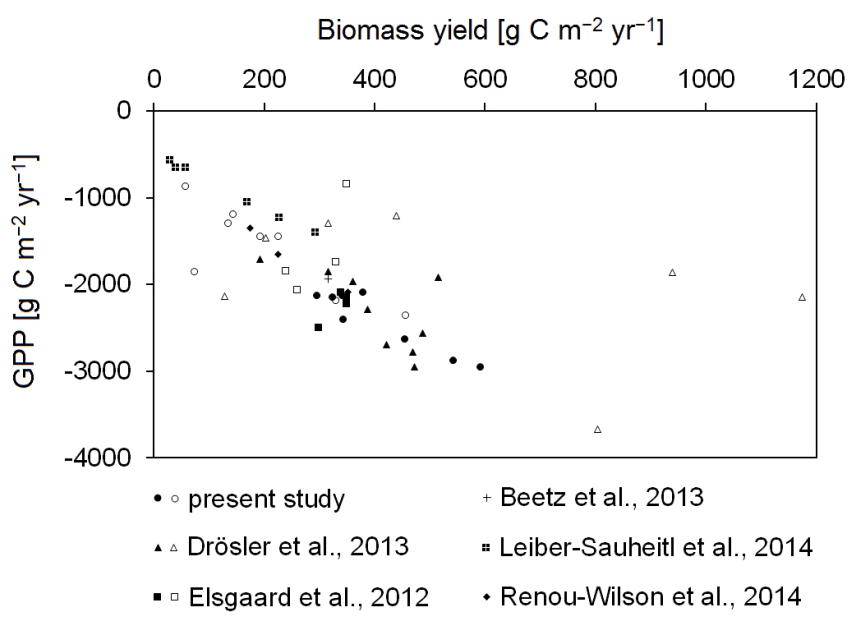

Figure 9. Relationship of GPP to biomass export from temperate peatlands. Solid symbols represents grassland sites (intensive and extensive); hollow symbols represents arable lands.

$R_{\mathrm{ECO}}$ and NEE for both years ( $R_{\mathrm{ECO}}$ only in 2010). Thus, modeled $R_{\text {ECO }}$ and calculated NEE rates should be considered to be a conservative estimation. However, modeled values fit well with values reported in the literature (see Fig. 9).

Several studies have indicated that dissolved organic $\mathrm{C}$ can significantly contribute to terrestrial C balances (e.g., Worrall et al., 2009; Dinsmore et al., 2010; Renou-Wilson et al., 2014). Thus, for the calculation of NECB from drained organic soils, fluvial $\mathrm{C}$ losses should additionally be considered in future investigations.

Observed $\mathrm{N}_{2} \mathrm{O}$ fluxes showed a high temporal variability with long periods of low background emissions and a few high peaks, mainly after management activities. Measurement frequency was increased after fertilization at the grassland plots for at least 2 weeks (see Eickenscheidt et al., 2014b), but due to our regular measurement intervals in the remaining year we cannot rule out that we may have missed high- $\mathrm{N}_{2} \mathrm{O}$ events driven by changing climate conditions (e.g., drying-rain or freeze-thaw events) and/or management activities, particularly at the arable sites. $\mathrm{N}_{2} \mathrm{O}$ peaks are known to last from a couple of days up to several weeks (Stolk et al., 2011). Due to our measurement intervals and interpolation approach, observed $\mathrm{N}_{2} \mathrm{O}$ and $\mathrm{CH}_{4}$ peaks distinctly altered the cumulative annual budgets, increasing the overall uncertainties in estimated GHG emissions. Furthermore, Christiansen et al. (2011) and Juszczak (2013) found that fluxes estimated in non-mixed chambers (without fans) were significantly underestimated (by up to $58 \%$ ) compared to the measured reference fluxes. Moreover, all gas fluxes were calculated solely by ordinary linear regression models, which potentially carries the risk of underestimating gas fluxes when compared to calculations using nonlinear functions (see, e.g., Pihlatie et al., 2013). Thus, it is possible that we systematically underestimated $\mathrm{N}_{2} \mathrm{O}$ and $\mathrm{CH}_{4}$ fluxes. However, for future inves- 


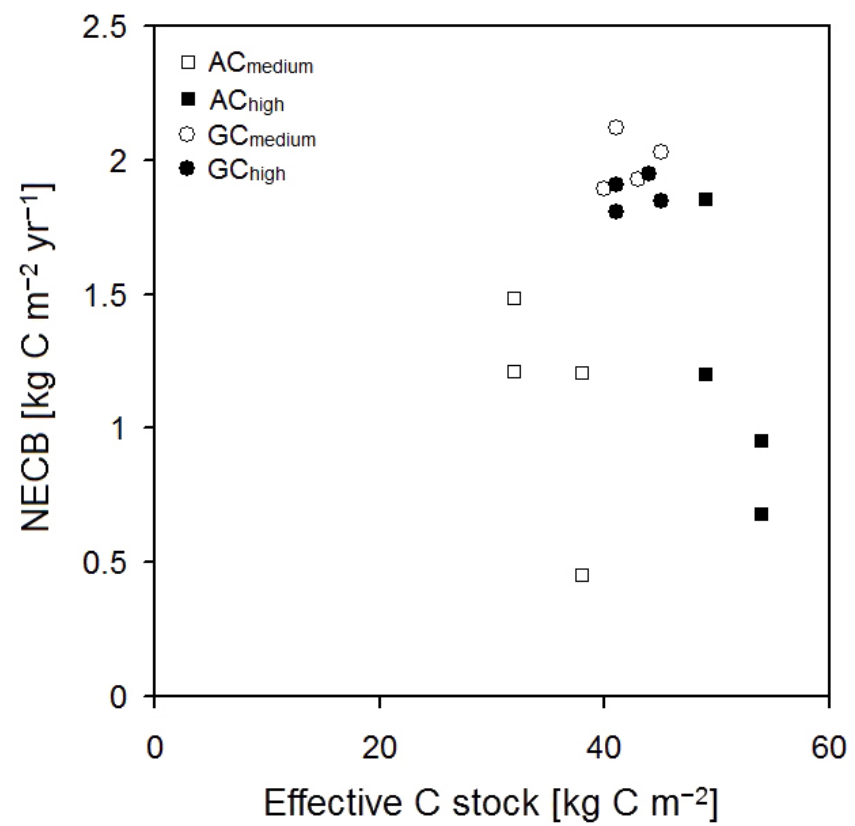

Figure 10. NECB plotted against the effective $C$ stock, which is defined as the fraction of aerated carbon in the soil profile (according to Leiber-Sauheitl et al., 2014) (calculated NECB did not include $\mathrm{CH}_{4}$ losses).

tigations into GHG emissions we strongly advocate, firstly, the combined use of automatic and manual chamber systems and, secondly, the testing of linear versus nonlinear models for gas flux calculation to obtain a higher accuracy of data.

\subsection{Soil organic carbon effects}

With the exception of $\mathrm{N}_{2} \mathrm{O}$, significantly different $\mathrm{GHG}$ emissions between the two soil types investigated were not found in the present study, although significantly different SOC contents in the upper soil horizon were detected. The observation contrasts strongly with our hypothesis that GHG emissions significantly increase with increasing SOM content (hypothesis i).

Regarding $\mathrm{CO}_{2}$ fluxes, the current findings are, however, in line with investigations from Leiber-Sauheitl et al. (2014), who reported that $\mathrm{CO}_{2}$ emissions were not related to different SOM contents in the upper horizon of an extensive grassland in northern Germany. By contrast, Veenendaal et al. (2007) and Renou-Wilson et al. (2014) assumed that their different estimated respiration rates for grassland sites were driven by different SOC or SOM contents. However, it can be assumed that not only the SOM content itself acts as a key factor controlling the $\mathrm{CO}_{2}$ release but that the proportion of SOM which is exposed to mineralization, which in turn is driven by drainage depth, also does so. Therefore, we calculated the effective $\mathrm{C}$ stock as the fraction of aerated carbon in the soil profile according to Leiber-Sauheitl et al. (2014) (Fig. 10). No relationship was found between the effective
C stock and the C flux components (expressed as NECB), which were also reported by Leiber-Sauheitl et al. (2014) and Tiemeyer et al. (2014). Moreover, Pohl et al. (2015) found that the static SOC stocks showed no significant effects on C fluxes of maize in a heterogenous peatland, whereas the dynamic $\mathrm{C}\left(\mathrm{SOC}_{\mathrm{dyn}}\right)$ and $\mathrm{N}\left(\mathrm{N}_{\mathrm{dyn}}\right)$ stocks and their interaction with $\mathrm{GW}$ level strongly influenced the $\mathrm{C}$ gas exchange. We also tried to apply the concept of $\mathrm{SOC}_{\mathrm{dyn}}$ and $\mathrm{N}_{\mathrm{dyn}}$ stocks as described in Pohl et al. (2015); however, neither contrasting them with the GW level nor contrasting them with the $\mathrm{SOC}_{\mathrm{dyn}}$ or with the $\mathrm{N}_{\mathrm{dyn}}$ had any explanatory power in our study. However, Fig. 10 shows that at the grassland sites, C stocks available for mineralization processes are comparable (40-45 $\mathrm{kg} \mathrm{C} \mathrm{m}^{-2}$ ), probably explaining the equal $\mathrm{CO}_{2}$ loss rates from this land-use type. Temperature and soil moisture are considered to be the primary regulators for $\mathrm{CO}_{2}$ emissions from soils (Silvola et al. 1996; Maljanen et al., 2001; Hardie et al., 2011), since they directly affect microbial activity and the rate of enzymatic processes (Michaelis and Menten, 1913; Tietema et al., 1992). In the present study, temperatures are found to be equal at all sites due to their close proximity, whereas the soil moisture contents differed significantly between the $\mathrm{C}_{\text {high }}$ and $\mathrm{C}_{\text {medium }}$ sites mainly due to the GW oscillation. It is well known that the water level height has a strong influence on $\mathrm{CO}_{2}$ emissions from peatlands as it directly affects the oxygen availability for microbial activity as was reported in several studies (e.g., Silvola et al., 1996; Berglund and Berglund, 2011; Renou-Wilson et al., 2014; Leiber-Sauheitl et al., 2014). Beside abiotic factors, substrate chemistry, in particular the SOM quality and its labile and more recalcitrant fractions, are considered to act as key variables affecting the decomposability of SOM and thus controlling $\mathrm{CO}_{2}$ fluxes from peatlands (Byrne and Farrell, 2005; Heller and Zeitz, 2012; Leifeld et al., 2012). For example, Leifeld et al. (2012) showed that the soil respiration rate of a disturbed temperate peatland was strongly controlled by its polysaccharide content; the O-alkyl-C content, in particular, was found to be a useful proxy for respiration rates. SOM quality was not examined in our study, but both soil types at all plots investigated exhibited highly decomposed organic material (H10, according to Von Post's humification scale; N. Roßkopf, personal communication, 2013). This is typical for organic soils which have been drained and intensively managed for a long time and is in line with Leifeld et al. (2012), who found that organic matter quality declines with ongoing decomposition, resulting in low polysaccharide contents and a lower availability for heterotrophic metabolism. Nevertheless, observed NECB revealed very high $\mathrm{C}$ loss rates from the SOC pool. Leifeld et al. (2014) suggested that intensive management, drainage and changed climate drivers accelerate peat decomposition today and therefore outweighed declining peat quality. Additionally, Reiche et al. (2010) reported that the degree of humification is not suitable for the prediction of $\mathrm{CO}_{2}$ and $\mathrm{CH}_{4}$ fluxes from anaerobic decomposition, which stands in 
contrast to assumptions made by Glatzel et al. (2004). However, observed equally narrow $\mathrm{C} / \mathrm{N}$ ratios $(10-12)$ in the upper soil reveal firstly a high organic-matter quality, easy to mineralize, and secondly comparable SOM qualities at all plots, probably explaining why no significantly different $\mathrm{C}$ loss rates between the two different soil types were found in the present study.

In line with $\mathrm{CO}_{2}, \mathrm{CH}_{4}$ fluxes were also not different between the two soil types investigated, but this can mainly be attributed to the intensive drainage and thus soil aeration, which effectively inhibited microbial methanogenesis at the $\mathrm{C}_{\text {medium }}$ and $\mathrm{C}_{\text {high }}$ sites. It is known that the availability and quality of organic substrates influences the amount of $\mathrm{CH}_{4}$ produced. Nevertheless, several studies indicate that high $\mathrm{CH}_{4}$ fluxes in bogs are mainly controlled by labile organic substrates such as root exudates or plant litter and not by bulk peat (Minchin and McNaughton, 1984; Chanton et al., 1995; Bridgham et al., 1998; Whalen, 2005; Hahn-Schöfl et al., 2011).

In contrast to $\mathrm{CO}_{2}$ and $\mathrm{CH}_{4}$ fluxes, $\mathrm{N}_{2} \mathrm{O}$ fluxes from the $\mathrm{C}_{\text {high }}$ sites significantly exceeded $\mathrm{N}_{2} \mathrm{O}$ fluxes from the $\mathrm{C}_{\text {medium }}$ sites. This can probably be attributed to the more favorable soil conditions for denitrification, supported by higher $\mathrm{N}_{\min }$ contents and higher groundwater levels at these sites (Eickenscheidt et al., 2014b). In both years $\mathrm{N}_{\min }$ was mainly dominated by $\mathrm{NO}_{3}^{-}$, demonstrating that net nitrification entirely controls net nitrogen mineralization at all plots. Thus, nitrification provided the substrate for denitrification and, additionally, may itself have contributed to $\mathrm{N}_{2} \mathrm{O}$ production. In general, $\mathrm{N}_{2} \mathrm{O}$ production processes are various and can occur simultaneously within close proximity (Davidson et al., 1986; Butterbach-Bahl et al., 2013). Both nitrification as well as denitrification depend on the availability of labile organic compounds as $\mathrm{C}$ and/or energy source (ButterbachBahl et al., 2013), in which autotrophic nitrification depends particularly on the availability of $\mathrm{CO}_{2}$ for cell growth (Delwiche and Finstein, 1965). However, for denitrification the actual regulation by $\mathrm{C}$ is currently not yet understood (Baggs and Philippot, 2011), but it can be assumed that sufficient metabolizable $\mathrm{C}$ was widely available at all plots investigated.

\subsection{Land-use and management effects}

On peatlands, GW level and land-use type are closely linked. From a meta-analysis of 53 German peatlands, Tiemeyer et al. (2013) found that the mean annual GW level was lower for arable land than for intensive grassland, with median GW levels of approximately -70 and $-37 \mathrm{~cm}$ below the soil surface. The GW levels observed in our study were on average lower for the arable land and higher for the grassland compared with the average of the meta-analysis. In general, intensive farming of peatlands presupposes low GW levels, since most of the arable crops are not adapted to low oxygen contents in the rhizosphere, as could be seen in the present study, where the temporarily high GW level or flooding caused plant damage and yield losses at the arable sites in 2010. The effect of reduced biomass productivity due to high GW levels which inhibited photosynthesis by slowing the rate of gas diffusion through the vegetation (Lohila, 2008) was also reported by Renou-Wilson et al. (2014). Both annual sums of GPP as well as yields were in good agreement with those reported from other peatlands as can be seen in Fig. 9. Statistical analysis revealed significantly higher yields at the grassland sites than at the arable sites, but it has to be taken into account that at the arable sites only the grains were harvested in 2011 and up to 3.84 and $9.05 \mathrm{t} \mathrm{DM} \mathrm{ha}^{-1}$ remained on the field in the oat and maize plots, respectively. Due to the continuous plant cover over the whole year at the grassland plots, annual sums of GPP were significantly higher at these plots than at the arable plots in 2010 as well as in 2011.

As with GPP, modeled annual sums of $R_{\mathrm{ECO}}$ differed significantly between the two land-use types with distinctly higher $R_{\mathrm{ECO}}$ values at the grassland sites. As mentioned above, $R_{\mathrm{ECO}}$ is strongly controlled by temperature since it stimulates both $R_{\mathrm{a}}$ and $R_{\mathrm{h}}$, as can be seen in the pronounced seasonality of $R_{\mathrm{ECO}}$. From the model fits it can be suggested that the more frequent model adaptation with $T_{\text {air }}(88 \%)$ reveals a higher share of $R_{\mathrm{a}}$ at the arable site than at the grassland sites. At the latter, approximately $40 \%$ of the $R_{\mathrm{ECO}}$ models were based on $\mathrm{ST}_{2}$, perhaps demonstrating a more balanced ratio of $R_{\mathrm{a}}$ to $R_{\mathrm{h}}$. Nevertheless, the proportion of the different respiration compartments of $R_{\mathrm{ECO}}$ is unknown, but Silvola et al. (1996) reported that root-derived respiration from grasslands established on peatland accounted for $35-45 \%$ of total soil respiration. Furthermore, Maljanen et al. (2001) found that root-associated respiration was distinctly higher on grasslands than on arable lands. However, the significantly higher $R_{\mathrm{ECO}}$ at the grassland sites may, firstly, be related to the higher biomass production at these sites, because a higher GPP also results in higher above- and belowground autotrophic respiration (Leiber-Sauheitl et al., 2014; Renou-Wilson et al., 2014). Moreover, the increased transport of photosynthates to the plant rhizosphere due to the higher GPP may favor bacterial metabolism through increased root exudates (Mounier et al., 2004; Henry et al., 2008; Sey et al., 2010), additionally enhancing $R_{\mathrm{h}}$. Secondly, the organic fertilizer application at the grassland plots stimulates microbial growth and thus SOM mineralization (Gutser et al., 2005; Jones et al., 2007). Additionally, a large part of the $\mathrm{C}$ from the organic fertilizer will quickly be metabolized to $\mathrm{CO}_{2}$ (Vuichard et al., 2007). Several authors (see, e.g., Dao, 1998; Maljanen et al., 2010) reported that regularly ploughed and fertilized arable lands are larger sources of $\mathrm{CO}_{2}$ than non-tilled arable land soils or grasslands, due to aerating and the mixing of crop residues into the soil. However, in the current study the effect of management is difficult to capture.

Despite higher modeled GPP values, the distinctly higher modeled $R_{\mathrm{ECO}}$ values led to significantly higher calculated 
NEE values at the grassland sites than at the arable sites. With the exception of the maize plot at the $\mathrm{C}_{\text {medium }}$ site in the year 2011, all plots show positive NEE balances in both years investigated, as expected for drained organic soils and as commonly reported in the literature (e.g., Maljanen et al., 2001; Grønlund et al., 2006, 2008; Maljanen et al., 2010; Elsgaard et al., 2012; Beetz et al., 2013; Drösler et al., 2013). However, the huge $\mathrm{CO}_{2}$ uptake capacity during the short growth period of the maize plants compensates for the soil $\mathrm{CO}_{2}$ release due to the microbial decomposition of organic matter at least in the year 2011. Nevertheless, as seen in the NECB, the C export also reversed the maize cultivation on the $\mathrm{C}_{\text {medium }}$ site to a $\mathrm{C}$ source. Previous studies of annual NEE from maize on organic soils are rare in the literature, but our results are in line with Drösler et al. (2013), who reported NEE values ranging from -216.2 to $443.8 \mathrm{~g} \mathrm{C} \mathrm{m}^{-2} \mathrm{yr}^{-1}$. As mentioned above, it has to be taken into account that in the year 2011 only the grains were harvested at all arable plots. Assuming that silage maize would have been produced instead of maize grains or the straw was additionally harvested at the oat plots, NECB would in part be doubled and more comparable to calculated grassland values.

According to Maljanen et al. (2010) the better aeration of regularly ploughed arable land leads to a larger sink of atmospheric $\mathrm{CH}_{4}$ than that at permanent grasslands. This contrasted with our results, where the $\mathrm{CH}_{4}$ fluxes from the arable plots significantly exceeded $\mathrm{CH}_{4}$ fluxes from the grassland plots. However, all measured $\mathrm{CH}_{4}$ fluxes were very low and $\mathrm{CH}_{4}$ emissions and uptakes were almost negligible in the NECB of the plots, as was also reported by several other authors for drained organic soils (e.g., Maljanen et al., 2010; Petersen et al., 2012; Schäfer et al., 2012; Drösler et al., 2013; Renou-Wilson et al., 2014). Moreover, the C import through fertilization contributed only marginally (3-14\%) to the NECB of the grassland plots.

In the course of the present study, fertilization was found to enhance $\mathrm{N}_{2} \mathrm{O}$ fluxes at the grassland sites, where the application of biogas digestate led to significantly higher $\mathrm{N}_{2} \mathrm{O}$ emissions than cattle slurry application did (for further discussion see Eickenscheidt et al., 2014b). From a meta-study of European organic soils, Leppelt et al. (2014) found that the amount of $\mathrm{N}$ fertilizer was directly linked to $\mathrm{N}_{2} \mathrm{O}$ fluxes from grasslands, whereas no significant relationship between $\mathrm{N}$ fertilization and $\mathrm{N}_{2} \mathrm{O}$ fluxes from arable lands were found. Nevertheless, $\mathrm{N}_{2} \mathrm{O}$ fluxes from the arable plots significantly exceeded those of the grassland sites, as was also reported by Maljanen et al. (2007, 2010) and Petersen et al. (2012) and additionally confirmed by Leppelt et al. (2014) for European organic soils. Observed $\mathrm{N}_{2} \mathrm{O}$ peaks at the arable sites can be related to harvesting and/or several consecutive tillage steps (e.g., ploughing, milling, and mattocking) in the previous weeks. This is in line with Silvan et al. (2005), who supposed that higher $\mathrm{N}_{2} \mathrm{O}$ fluxes from arable lands are related to the higher $\mathrm{N}$ availability for microbial denitrification in the absence of plants. No fertilizer was applied to the arable plots, which is also reflected in the significantly lower $\mathrm{N}_{\text {min }}$ contents and perhaps in $\mathrm{pH}$ values that are higher in arable plots than in the grassland plots. However, it is well known that drainage and intensive management enhanced the degradation of SOM and thus stimulates net nitrogen mineralization and nitrogen transformation processes (KasimirKlemedtsson et al., 1997; Freibauer et al., 2004; Goldberg et al., 2010). Several authors reported an annual N supply through peat mineralization of approximately $70-425 \mathrm{~kg}$ $\mathrm{N} \mathrm{ha}^{-1} \mathrm{yr}^{-1}$ (Schothorst, 1977; Flessa et al., 1998; Sonneveld and Lantinga, 2011; Leppelt et al., 2014). Taking into account the calculated soil carbon losses and plot-specific $\mathrm{C} / \mathrm{N}$ ratios of the upper soil or peat layer, estimated SOM mineralization leads to an annual $\mathrm{N}$ supply of approximately $451-1720 \mathrm{~kg} \mathrm{Nha}^{-1} \mathrm{yr}^{-1}$. This estimation seems very high but regardless of the high uncertainties it clearly indicates that sufficient $\mathrm{N}$ must be available for nitrification and denitrification, independently of fertilizer application as previously assumed by Leppelt et al. (2014). Furthermore, the admixture of Vicia sativa or Vicia faba minor, both $\mathrm{N}_{2}$ fixing leguminoses further increase the soil $\mathrm{N}_{\min }$ pool of the arable sites through the release of $\mathrm{N}$-rich root exudates (Rochette et al. 2004; Sey et al., 2010) as well as their incorporation into the soil, albeit to an unknown extent.

In conclusion, taking together estimated GHG emissions, calculated GWPs clearly differ between the two land-use types investigated, with distinctly higher GWPs observed at the grassland plots than on the arable land. However, all plots show a very high release of GHGs, demonstrating the unsustainable agricultural use of drained organic soils and the current need for the implementation of mitigation strategies and restoration measures. We hypothesized that GHG emissions from arable soils exceed GHG emissions from intensively managed grassland soils. The contrary was found in the present study; therefore, we have to reject hypothesis ii. However, from the present results it can be concluded that mainly the management, and not the land-use type itself or the SOC content, is responsible for the amount of GHGs released from the intensive farming of drained organic soils.

\subsection{Implications for the climate reporting under LULUCF/AFOLU}

For the climate reporting under LULUCF/AFOLU, the IPCC guidelines consider GHG emissions from peat soils that have a soil or peat layer that is at least $\geq 10 \mathrm{~cm}$ thick and a $\mathrm{C}_{\mathrm{org}}$ content of $\geq 12 \%$ in the case of a soil thickness of $\leq 20 \mathrm{~cm}$. However, the intensive cultivation of organic soils leads to a continuous decrease in the amount of SOM, and thus the area of soils which fulfil the requirements of the IPCC guidelines for organic soils have rapidly declined in the last decades. For example, Nielsen et al. (2012) reported an average annual decrease in organic soils of approximately 1400 ha in Denmark since 1975 . The remaining soils often contain $>6 \% \mathrm{C}_{\text {org }}$ and not the required $>12 \%$ (Nielsen et al., 2012). Contrary 
to mineral soils or natural peatlands in equilibrium, Nielsen et al. (2012) assume that drained and managed soils having $>6 \% \mathrm{C}_{\text {org }}$ will evidently lose carbon until a new equilibrium is reached. Since no data were available in the literature for these soils, Nielsen et al. (2012) decided to allocate a fixed emission factor that is half of what was measured for soils having $>12 \% \mathrm{C}_{\text {org }}$ to account for these losses in the Danish greenhouse gas inventory. However, despite being subject to high uncertainties, our results reveal that the GHG emission potential of soils intermediate between mineral and organic soils can be as high as or sometimes higher than for typical drained organic soils under intensive agricultural use. This is in line with observations from Leiber-Sauheitl et al. (2013) for extensive grasslands. To avoid a significant underestimation of GHG emissions in the LULUCF/AFOLU sector, there is a corresponding need to adjust the IPCC guidelines for drained inland organic soils accordingly. The new 2013 Supplement to the IPCC guidelines for national GHG inventories on wetlands distinguishes several emission factors for different land-use types, climate regions, nutrient statuses and drainage intensities (IPCC, 2014). We suggest establishing a further category which provides emission factors for different land-use types at former drained peatlands or associated organic soils, which do not fulfil the necessary requirements of typical organic soils but also contain high amounts of $\mathrm{C}_{\text {org }}$. To define reliable emissions factors for these soils, further investigations regarding their potential to release GHGs are needed. Furthermore, it has to be clarified to what extent the composition of the SOM is responsible for the magnitude of GHG release from drained organic soils.

\section{Conclusions}

This study presents estimations of GHG fluxes from arable lands and intensive grasslands on Sapric Histosol and Mollic Gleysol, which differed significantly in their SOC content in the topsoil. Despite a high uncertainty in GHG flux estimations and modeling, the present results clearly revealed that, like typical drained peatlands, drained Mollic Gleysols can also be considered to be hotspots for GHG emissions, provided that they are intensively managed as arable land or grassland. However, observed GHG fluxes revealed a very high sensitivity to changing key factors such as climate variables (e.g., temperature and precipitation) and management. Estimated GHG emission factors sometimes more than doubled the emission factor of the Tier 1 approach of the IPCC independent of the SOC content in the topsoil. Thus, former peatlands and associated organic soils, containing $<12 \%$ $\mathrm{C}_{\text {org }}$ should be integrated into the national GHG emission inventories to avoid a significant underestimation of the climate reporting. Moreover, there is a current need to adjust the IPCC guidelines for drained inland organic soils accordingly. Besides climate reporting, the observed very high release of GHGs demonstrates the unsustainable agricultural use of drained organic soils and the current need for rapid implementation of mitigation strategies and restoration measures.

\section{The Supplement related to this article is available online at doi:10.5194/bg-12-5161-2015-supplement.}

Acknowledgements. We thank the two anonymous referees for their careful reading of the manuscript and suggestions which have greatly improved the paper. Furthermore, we thank the landowners Georg Baumgartner, Ludwig Büchler and Josef Pellmeyer for the opportunity to conduct the measurements during the regular management as well for their excellent cooperation and help. Moreover, we would thank Niko Roßkopf (Humboldt-Universität zu Berlin) for soil description as well as Stephan Raspe from the Bavarian State Institute of Forestry for providing the $\mathrm{N}$ deposition data. Further, the authors thank Nadine Eickenscheidt (Thünen Institute) for helpful discussion and critical reviewing as well as all voluntary and student helpers, namely Lukas Aberl, Kevin Hose, Elsa Florentine Kündiger, Claudia Kurzböck, Melissa Mayer, Phillip Metzner, Björn Ridders, Anna Steinert, Benedikt Springer, Moritz Then and Jonas Weng, for their help during fieldwork. The publication was supported by the German Research Foundation (DFG) and the Technische Universität München (TUM) by the funding programme "Open Access Publishing". This study was part of the joint research project "Organic soils: acquisition and development of methods, activity data and emission factors for the climate reporting under LULUCF/AFOLU", funded by the Thünen Institute.

This work was supported by the German Research Foundation (DFG) and the Technische Universität München within the funding programme

Open Access Publishing.

Edited by: Y. Kuzyakov

\section{References}

Ad-Hoc-AG Boden: Bodenkundliche Kartieranleitung, 5. Aufl., Schweizerbart'sche Verlagsbuchhandlung, Hannover, 438 pp., 2005.

Alm, J., Shurpali, N. J., Tuittila, E.-S., Laurila, T., Maljanen, M., Saarnio, S., and Minkkinen, K.: Methods for determining emission factors for the use of peat and peatlands - flux measurements and modeling, Boreal Environ. Res., 12, 85-100, 2007.

Augustin, J., Merbach, W., Steffens, L., and Snelinski, B.: Nitrous Oxide Fluxes of Disturbed Minerotrophic Peatlands, Agribiol. Res., 51, 47-57, 1998.

Baggs, E. M. and Philippot, L.: Nitrous oxide production in the terrestrial environment, Nitrogen Cycl, In Bacteria: Molecular Analysis, Caister Academic Press, England, 211-232, 2011.

Beetz, S., Liebersbach, H., Glatzel, S., Jurasinski, G., Buczko, U., and Höper, H.: Effects of land-use intensity on the full green- 
house gas balance in an Atlantic peat bog, Biogeosciences, 10, 1067-1082, doi:10.5194/bg-10-1067-2013, 2013.

Berglund, Ö. and Berglund, K.: Influence of water table level and soil properties on emissions of greenhouse gases from cultivated peat soil, Soil Biol. Biochem., 43, 923-931, 2011.

Blodau, C.: Carbon cycling in peatlands - A review of processes and controls, Environ. Rev., 10, 111-134, 2002.

Bridgham, S.D., Updegraff, K., and Pastor, J.: Carbon, nitrogen, and phosphorus mineralization in northern wetlands, Ecology, 79, 1545-1561, 1998,

Butterbach-Bahl, K., Baggs, E. M., Dannenmann, M., Kiese, R., and Zechmeister-Boltenstern, S.: Nitrous oxide emissions from soils: how well do we understand the processes and their controls?, Phil. Trans. R Soc. B, 368, 1621, doi:10.1098/rstb.2013.0122, 2013.

Byrne, K. A. and Farrell, E. P.: The effect of afforestation on soil carbon dioxide emissions in blanket peatland in Ireland, Forestry, 78, 217-227, 2005.

Chanton, J. P., Bauer, J. E., Glaser, P. A., Siegel, D. I., Kelley, C. A., Tyler, S. C., Romanowicz, E. H., and Lazrus, A.: Radiocarbon evidence for the substrates supporting methane formation within northern Minnesota peatlands, Geochim. Cosmochim. Acta, 59, 3663-3668, 1995.

Chapin, F. S., Woodwell, G. M., Randerson, J. T., Rastetter, E. B., Lovett, G. M., Baldocchi, D. D., Clark, D. A., Harmon, M. E., Schimel, D. S., Valentini, R., Wirth, C., Aber, J. D., Cole, J. J., Goulden, M. L., Harden, J. W., Heimann, M., Howarth, R. W., Matson, P. A., McGuire, A. D., Melillo, J. M., Mooney, H. A., Neff, J. C., Houghton, R. A., Pace, M. L., Ryan, M. G., Running, S. W., Sala, O. E., Schlesinger, W. H., and Schulze, E.-D.: Reconciling Carbon-cycle Concepts, Terminology, and Methods, Ecosystems, 9, 1041-1050, 2006.

Christiansen, J. R., Korhonen, J. F. J., Juszczak, R., Giebels, M., and Pihlatie, M.: Assessing the effects of chamber placement, manual sampling and headspace mixing on $\mathrm{CH}_{4}$ fluxes in a laboratory experiment, Plant Soil, 343, 171-185, 2011.

Couwenberg, J.: Greenhouse gas emissions from managed peat soils: is the IPCC reporting guidance realistic, Mires Peat, $8,1-$ 10, 2011.

Crawley, M. J.: The R Book, John Wiley and Sons Ltd, Chichester, p. 942, 2007.

Crutzen, P. J.: the role of $\mathrm{NO}$ and $\mathrm{NO}_{2}$ in the chemistry of the troposphere and stratosphere, Annu. Rev. Earth Planet. Sci., 7, 443472, 1979.

Dao, T. H.: Tillage and crop residue effects on carbon dioxide evolution and carbon storage in a paleustoll, Soil Scie. Soc. Am. J., 62, 250-256, 1998.

Davidson, E. A., Swank, W. T., and Perry, T. O.: Distinguishing between nitrification and denitrification as sources of gaseous nitrogen production in soil, Appl. Environ. Microbiol., 52, 12801286, 1986.

Delwiche, C. C. and Finstein, M. S.: Carbon and energy source for the nitrifying autotroph Nitrobacter, J. Bacteriol., 90, 102-107, 1965.

Dinsmore, K. J., Billet, M. F., Skiba, U. M., Rees, R. M., Drewer, J., and Helfter, C.: Role of the aquatic pathway in the carbon and greenhouse gas budgets of a peatland catchment, Glob. Change Biol., 16, 2750-2762, 2010.
Drösler, M.: Trace gas exchange and climatic relevance of bog ecosystems, Southern Germany, PhD thesis, Chair of Vegetation Ecology, Department of Ecology, Technical University Munich, p. 179, 2005.

Drösler, M., Freibauer, A., Christensen, T., and Friborg, T.: Observation and status of peatland greenhouse gas emission in Europe, in: The Continental-Scale Greenhouse Gas Balance of Europe, edited by: Dolman, H., Valentini, R. and Freibauer, A., Ecological Studies, 203, 237-255, 2008.

Drösler, M., Freibauer, A., Adelmann, W., Augustin, J., Bergman, L., Beyer, C., Chojnicki, B., Förster, C., Giebels, M., Görlitz, S., Höper, H., Kantelhardt, J., Liebersbach, H., HahnSchöfl, M., Minke, M., Petschow, U., Pfadenhauer, J., Schaller, L., Schägner,P., Sommer, M., Thuille, A., and Wehrhan, M.: Klimaschutz durch Moorschutz in der Praxis, Arbeitsbericht aus dem vTI-Institut für Agrarrelevante Klimaforschung, p. 21, available at: http://www.vti.bund.de/de/startseite/institute/ak/ publikationen.html (last access: November 2014), 2011.

Drösler, M., Adelmann, W., Augustin, J., Bergmann, L., Beyer, C., Chojnicki, B., Förster, C., Freibauer, A., Giebels, M., Görlitz, S., Höper, H., Kantelhardt, J., Liebersbach, H., Hahn-Schöfl, M., Minke, M., Petschow, U., Pfadenhauer, J., Schaller, L., Schägner, P., Sommer, M., Thuille, A., and Wehrhan, M.: Klimaschutz durch Moorschutz. Schlussbericht des Vorhabens "Klimaschutz - Moorschutzstrategien”, 2006-2010, 2013.

Eickenscheidt, T., Heinichen, J., Augustin, J., Freibauer, A., and Drösler, M.: Nitrogen mineralization and gaseous nitrogen losses from waterlogged and drained organic soils in a black alder (Alnus glutinosa (L.) Gaertn.) forest, Biogeosciences, 11, 29612976, doi:10.5194/bg-11-2961-2014, 2014a.

Eickenscheidt, T., Freibauer, A., Heinichen, J., Augustin, J., and Drösler, M.: Short-term effects of biogas digestate and cattle slurry application on greenhouse gas emissions affected by $\mathrm{N}$ availability from grasslands on drained fen peatlands and associated organic soils, Biogeosciences, 11, 6187-6207, doi:10.5194/bg-11-6187-2014, 2014b.

Elsgaard, L., Gorres, C.-M., Hoffmann, C. C., Blicher-Mathiesen, G., Schelde, K., and Petersen, S. O.: Net ecosystem exchange of $\mathrm{CO}_{2}$ and carbon balance for eight temperate organic soils under agricultural management, Agr. Ecosyst. Environ., 162, 5267, 2012.

Falge, E., Baldocchi, D., Olson, R., Anthoni, P., Aubinet, M., Bernhofer, C., Burba, G., Ceulemans, R., Clement, R., Dolman, H., Granier, A., Gross, P., Grunwald, T., Hollinger, D., Jensen, N. O., Katul, G., Keronen, P., Kowalski, A., Lai, C. T., Law, B. E., Meyers, T., Moncrieff, H., Moors, E., Munger, J. W., Pilegaard, K., Rannik, U., Rebmann, C., Suyker, A., Tenhunen, J., Tu, K., Verma, S., Vesala, T., Wilson, K., and Wofsy, S.: Gap filling strategies for defensible annual sums of net ecosystem exchange, Agr. Forest Meteorol., 107, 43-69, 2001.

Flessa, H., Wild, U., Klemisch, M., and Pfadenhauer, J.: C- und NStoffflüsse auf Torfstichsimulationsflächen im Donaumoos, Z. f. Kulturtechnik und Landentwicklung, 38, 11-17, 1997.

Flessa, H., Wild, U., Klemisch, M., and Pfadenhauer, J.: Nitrous oxide and methane fluxes from organic soils under agriculture, Europ. J. Soil Sci., 49, 327-335. 1998.

Forster, P., Ramaswamy, V., Artaxo, P., Berntsen, T., Betts, R., Fahey, D. W., Haywood, J., Lean, J., Lowe, D. C., Myhre, G., Nganga, J., Prinn, R., Raga, G., Schulz, M., and Van Dorland, 
R.: Changes in Atmospheric Constituents and in Radiative Forcing, in: Climate Change 2007: The Physical Science Basis. Contribution of Working Group I to the Fourth Assessment Report of the Intergovernmental Panel on Climate Change, edited by: Solomon, S., Qin, D., Manning, M., Chen, Z., Marquis, M., Averyt, K. B., Tignor, M., and Miller, H. L., Cambridge University Press, Cambridge, United Kingdom and New York, NY, USA, 129-234, 2007.

Freibauer, A., Rounsevell, M. D. A., Smith, P., and Verhagen, J.: Carbon sequestration in the agricultural soils of Europe, Geoderma, 122, 1-23, 2004.

Glatzel, S., Basiliko, N., and Moore, T.: Carbon dioxide and methane production potential of peats from natural, harvested and restored sites, Eastern Québec, Canada, Wetlands, 24, 261267, 2004.

Goldberg, S. D., Knorr, K. H., Blodau, C., Lischeid, G., and Gebauer, G.: Impact of altering the water table height of an acidic fen on $\mathrm{N}_{2} \mathrm{O}$ and $\mathrm{NO}$ fluxes and soil concentrations, Global Change Biol., 16, 220-233, 2010.

Grønlund, A., Sveistrup, T. E., Søvik, A. K., Rasse, D. P., and Kløve, B.: Degradation of cultivated peat soils in northern Norway based on field scale $\mathrm{CO}_{2}, \mathrm{~N}_{2} \mathrm{O}$ and $\mathrm{CH}_{4}$ emission measurements, Arch Agron. Soil Sci., 52, 149-159, 2006.

Grønlund, A., Hauge, A., Hovde, A., and Rasse, D.A.: Carbon loss estimates from cultivated peat soils in Norway: a comparison of three methods, Nutr. Cycl. Agroecosyst., 81, 157-167, 2008.

Grosse, W., Frye, J., and Lattermann, S.: Root aeration in wetland trees by pressurized gas transport, Tree Physiol., 10 285-295, 1992.

Gupta, H. V., Sorooshian, S., and Yapo, P. O.: Status of automatic calibration for hydrologic models: Comparison with multilevel expert calibration, J. Hydrologic Eng., 4, 135-143, 1999.

Gutser, R., Ebertseder, Th., Weber, A., Schraml, M., and Schmidhalter, U.: Short-term and residual availability of nitrogen after long-term application of organic fertilizers on arable land, J. Plant Nutr. Soil Sci., 168, 439-446, 2005.

Hahn-Schöfl, M., Zak, D., Minke, M., Gelbrecht, J., Augustin, J., and Freibauer, A.: Organic sediment formed during inundation of a degraded fen grassland emits large fluxes of $\mathrm{CH}_{4}$ and $\mathrm{CO}_{2}$, Biogeosciences, 8, 1539-1550, doi:10.5194/bg-8-15392011, 2011.

Hardie, S. M. L., Garnett, M. H., Fallick, A. E., Rowland, A. P., Ostle, N. J., and Flowers, T. H.: Abiotic drivers and their interactive effect on the flux and carbon isotope $\left({ }^{14} \mathrm{C}\right.$ and $\left.\delta^{13} \mathrm{C}\right)$ composition of peat-respired $\mathrm{CO}_{2}$, Soil Biol. Biochem., 43, 2432-2440, 2011.

Heller, C. and Zeitz, J.: Stability of soil organic matter in two northeastern German fen soils: the influence of site and soil development, J. Soil. Sedim., 12, 1231-1240, 2012.

Henry, S., Texier, S., Hallet, S., Bru, D., Dambreville, C., Chèneby, D., Bizouard, F., Germon, J. C., and Philippot, L.: Disentangling the rhizosphere effect on nitrate reducers and denitrifiers: insight into the role of root exudates, Environ. Microbiol., 10, 30823092, 2008.

Höper, H., Augustin, J., Cagampan, J. P., Drösler, M., Lundin, L., Moors, E. J., Vasander, H., Waddington, J. M., and Wilson, D.: Restoration of peatlands and greenhouse gas balances, in: Peatlands and Climate Change. edited by: Strack, D. M., International Peat Society, Jyvaskyla, 182-210, 2008.
Horrocks, R. D. and Valentine, J. F.: Harvested forages, Academic Press, 1999.

Hothorn, T., Bretz, F., Westfall, P., Heiberger, R. M., and Schuetzenmeister, A.: Simultaneous Inference in General Parametric Models: R package version 1, 2-17, 2013.

International Peat Society: Peatlands and climate change, edited by: Strack, M., Publish by the International Peat Society, p. 227, 2008.

IPCC: Changes in atmospheric constituents and in radiative forcing, in: Climate Change 2007: The physical science basis. Contribution of Working Group I to the Fourth Assessment Report of the Intergovernmental Panel on Climate Change, edited by: Solomon, S., Qin, D., Manning, M., Chen, Z., Marquis, M., Averyt, K. B., Tignor, M., and Miller, H. L., Cambridge University Press, Cambridge, UK and New York, USA, p. 996, 2007.

IPCC, 2014: 2013 Supplement to the 2006 IPCC Guidelines for National Greenhouse Gas Inventories: Wetlands, editd by: Hiraishi, T., Krug, T., Tanabe, K., Srivastava, N., Baasansuren, J., Fukuda, M., and Troxler, T. G., IPCC, Switzerland, 2014.

Jones, S. K., Rees, R. M., Skiba, U. M., and Ball, B. C.: Influence of organic and mineral $\mathrm{N}$ fertiliser on $\mathrm{N}_{2} \mathrm{O}$ fluxes from temperate grassland, Agriculture, Ecosyst. Environ., 121, 74-83, 2007.

Juszazak, R.: Biases in methane chamber measurements in peatland, Int. Agrophys., 27, 159-168, 2013.

Kandel, T. P., Elsgaard, L., Karki, S., and Læerke, P. E.: Biomass yield and greenhouse gas emissions from a drained fen peatland cultivated with reed canary grass under different harvest and fertilizer regimes, Bioenerg. Res., 6, 883-895, 2013.

Kasimir-Klemedtsson, Å., Klemedtsson, L., Berglund, K., Martikainen, P., Silvola, J., and Oenema, O.: Greenhouse gas emissions from farmed organic soils: a review, Soil Use and Management, 13, 245-250, 1997.

Kroeze, C., Mosier, A., and Bouwman, L.: Closing the global $\mathrm{N}_{2} \mathrm{O}$ budget: A retrospective analysis 1500-1994, Global Biogeochem. Cy., 13, 1-8, 1999.

Leiber-Sauheitl, K., Fuß, R., Voigt, C., and Freibauer, A.: High $\mathrm{CO}_{2}$ fluxes from grassland on histic Gleysol along soil carbon and drainage gradients, Biogeosciences, 11, 749-761, doi:10.5194/bg-11-749-2014, 2014.

Leifeld, J., Müller, M., and Fuhrer, J.: Peatland subsidence and carbon loss from drained temperate fens, Soil Use Manage., 27, 170-176, 2011.

Leifeld, J., Steffens, M., and Galego-Sala, A.: Sensitivity of peatland carbon loss to organic matter quality, Geophys. Res. Lett., 39, L14704, doi:10.1029/2012GL051856, 2012.

Leifeld, J., Bader, C., Borraz, E., Hoffmann, M., Giebels, M., Sommer, M., and Augustin, J.: Are C-loss rates from drained peatlands constant over time? The additive value of soil profile based and flux budget approach, Biogeosciences Discuss., 11, 1234112373, doi:10.5194/bgd-11-12341-2014, 2014.

Leppelt, T., Dechow, R., Gebbert, S., Freibauer, A., Lohila, A., Augustin, J., Drösler, M., Fiedler, S., Glatzel, S., Höper, H., Järveoja, J., Lærke, P. E., Maljanen, M., Mander, Ü., Mäkiranta, P., Minkkinen, K., Ojanen, P., Regina, K., and Strömgren, M.: Nitrous oxide emission budgets and land-use-driven hotspots for organic soils in Europe, Biogeosciences, 11, 65956612, doi:10.5194/bg-11-6595-2014, 2014.

Livingston, G. P. and Hutchinson, G. L.: Enclosure-based measurement of trace gas exchange: application and sources of error, In: 
Matson, PA, Harriss, RC, (eds.), Biogenic Trace Gases: Measuring Emissions from Soil and Water, Blackwell Science, Cambridge, 14-50, 1995.

Lloyd, J. and Taylor, J. A.: On the temperature dependence of soil respiration, Funct. Ecol., 8, 315-323, 1994.

Lohila, A.: Carbon dioxide exchange on cultivated and afforested boreal peatlands, Finn. Meteorol. Instit. Contribut., 73, 1-47, 2008.

Maljanen, M., Hytönen, J., and Martikainen, P. J.: Fluxes of $\mathrm{N}_{2} \mathrm{O}$, $\mathrm{CH}_{4}$ and $\mathrm{CO}_{2}$ on afforested boreal agricultural soils, Plant Soil, 231, 113-121, 2001.

Maljanen, M., Hytönen, J., Mäkiranta, P., Alm, J., Minkkinen, K., Laine, J. and Martikainen, P. J.: Greenhouse gas emissions from cultivated and abandoned organic arable lands in Finland, Boreal Environ. Res., 12, 133-144, 2007.

Maljanen, M., Sigurdsson, B. D., Guðmundsson, J., Óskarsson, H., Huttunen, J. T., and Martikainen, P. J.: Greenhouse gas balances of managed peatlands in the Nordic countries - present knowledge and gaps, Biogeosciences, 7, 2711-2738, doi:10.5194/bg7-2711-2010, 2010.

Martikainen, P. J., Nykänen, H., Crill, P., and Silvola, J.: Effect of a lowered water table on nitrous oxide fluxes from northern peatlands, Nature, 366, 51-53, 1993.

Matsuura, S., Mori, A., Hojito, M., Kanno, T., and Sasaki, H.: Evaluation of a portable chamber system for soil $\mathrm{CO} 2$ efflux measurement and the potential errors caused by internal compensation and water vapor dilution, J. Agric. Meteorol., 67, 127-137, 2011.

Michaelis, L. and Menten, M. L.: Die Kinetik der Invertinwirkung, Biochem. Z., 49, 333-369, 1913.

Minchin, P. E. H. and McNaughton, G. S.: Exudation of recently fixed carbon by non-sterile roots, J. Experiment. Botany, 35, 74 82, 1984.

Moriasi, D. N, Arnold, J. G., Van Liew, M. W., Bingner, R. L., Harmel, R. D., and Veith, T. L.: Model evaluation guidelines for systematic quantification of accuracy in watershed simulations, Am. Soc. Agr. Biolo. Engin., 50, 885-900, 2007.

Mounier, E., Hallet, S., Chèneby, D., Benizri, E., Gruet, Y., Nguyen, C., Piutti, S., Robin, C., Slezack-Deschaumes, S., MartinLaurent, F., Germon, J. C., and Philippot, L.: Influence of maize mucilage on the diversity and activity of the denitrifying community, Environ. Microbiol., 6, 301-312, 2004.

Nash, J. E. and Sutcliffe, J. V.: River flow forecasting through conceptual models: Part 1. A discussion of principles, J. Hydrology, 10, 282-290, 1970.

Nielsen, O.-K., Mikkelsen, M. H., Hoffmann, L., Gyldenkærne, S., Winther, M., Nielsen, M., Fauser, P., Thomsen, M., Plejdrup, M. S., Albrektsen, R., Hjelgaard, K., Bruun, H. G., Johannsen, V. K., Nord-Larsen, T., Bastrup-Birk, A., Vesterdal, L., Møller, I. S., Rasmussen, E., Arfaoui, K., Baunbæk, L., and Hansen, M. G.: Denmark's National Inventory Report 2012. Emission Inventories 1990-2010 - Submitted under the United Nations Framework Convention on Climate Change and the Kyoto Protocol. Aarhus University, DCE - Danish Centre for Environment and Energy, Scientific Report from DCE - Danish Centre for Environment and Energy No. 19 http://www.dmu.dk/Pub/SR19.pdf (last access: December 2013), 1168 pp. 2012.

NIR 2010: National Emission Inventory Report (NIR) 2010 for 2008 - Calculation of Emissions from German Agriculture, Ed.
Haenel, H.D., vTI Agriculture and Forestry Research, Special Issue 334, p. 428, 2010.

Pérez-Priego, O., Lópes-Ballesteros, A., Sánchez-Cañete, E. P., Serrano-Ortiz, P., Kutzbach, L., Domingo, F., Eugster, W., and Kowalski, A. S.: Analysing uncertainties in the calculation of fluxes using whole-plant chambers: random and systematic errors, Plant soil, 391, 229-244, doi:10.1007/s11104-015-2481-x, 2015.

Petersen, S. O., Hoffmann, C. C., Schäfer, C.-M., BlicherMathiesen, G., Elsgaard, L., Kristensen, K., Larsen, S. E., Torp, S. B., and Greve, M. H.: Annual emissions of $\mathrm{CH}_{4}$ and $\mathrm{N}_{2} \mathrm{O}$, and ecosystem respiration, from eight organic soils in Western Denmark managed by agriculture, Biogeosciences, 9, 403-422, doi:10.5194/bg-9-403-2012, 2012.

Pihlatie M., Christiansen, J. R., Aaltonen, H., Korhonen, J. F. J., Nordbo, A., Rasilo, T., Benanti, G., Giebels, M., Helmy, M., Sheehy, J., Jones, S., Juszczak, R., Klefoth, R., Lobo do Vale, R., Rosa, A.P., Schreiber, P., Serça, D., Vicca, S., Wolf B., and Pumpanen J.: Comparison of static chambers to measure $\mathrm{CH}_{4}$ emissions from soils, Agr. For. Met., 171-172, 124-136, 2013.

Pohl, M., Hoffmann, M., Hagemann, U., Giebels, M., Albiac Borraz, E., Sommer, M., and Augustin, J.: Dynamic C and N stocks key factors controlling the $\mathrm{C}$ gas exchange of maize in heterogenous peatland, Biogeosciences, 12, 2737-2752, doi:10.5194/bg12-2737-2015, 2015.

R Development Core Team: R: A language and environment for statistical computing, R Foundation for Statistical Computing, Vienna, Austria, ISBN 3-900051-07-0, available at: http://www. R-project.org (last access: December 2013), 2013.

Reiche, M., Gleixner, G., and Küsel, K.: Effect of peat quality on microbial greenhouse gas formation in an acidic fen, Biogeosciences, 7, 187-198, doi:10.5194/bg-7-187-2010, 2010.

Renou-Wilson, F., Barry, C., Müller, C., and Wilson, D.: The impacts of drainage, nutrient status and management practice on the full carbon balance of grasslands on organic soils in a maritime temperate zone, Biogeosciences, 11, 4361-4379, doi:10.5194/bg-11-4361-2014, 2014.

Rochette, P., Angers, D. A., Belanger, G., Chantigny, M. H., Prevost, D., and Levesque, G.: Emissions of $\mathrm{N}_{2} \mathrm{O}$ from alfalfa and soybean crops in eastern Canada, Soil Sci. Soc. Am. J., 68, 493506, 2004.

Schäfer, C. M., Elsgaard, L., Hoffmann, C. C., and Petersen, S. O.: Seasonal methane dynamics in three temperate grasslands on peat, Plant Soil, 357, 339-353, 2012.

Schober, H. M., Stein, Ch., and Prösl, K.-H: Interkommunales Flächenmanagement Schlussbericht, LEADER+-Projekt Freisinger Moos, p. 56, 2008.

Schothorst, C. J.: Subsidence of low moor peat soils in the Western Netherlands, Geoderma, 17, 265-291, 1977.

Sey, B. K., Manceur, A. M., Wahlen, J. K., Gregorich, E. G, and Rochette, P.: Root-derived respiration and nitrous oxide production as affected by crop phenology and nitrogen fertilization, Plant Soil, 326, 369-379, 2010.

Silvan, N., Tuittila, E.-S., Kitunen, V., Vasander, H., and Laine, J.: Nitrate uptake by Eriophorum vaginatum controls $\mathrm{N}_{2} \mathrm{O}$ production in a restored peatland, Soil Biol. Biochem., 37, 1519-1526, 2005. 
Silvola, J., Alm, J., Ahlolm, U., Nykänen, H., and Martikainen, P. J.: $\mathrm{CO}_{2}$ fluxes from peat in boreal mires under varying temperature and moisture conditions, J. Ecol., 84, 219-228, 1996.

Solomon, S.: Stratospheric ozone depletion: A review of concepts and history, Rev. Geophys., 37, 275-316, 1999.

Sonneveld, M. P. W. and Lantinga, E. A.: The contribution of mineralization to grassland $\mathrm{N}$ uptake on peatland soils with anthropogenic A horizons, Plant Soil, 340, 357-368, 2011.

Stolk, P. C., Hendriks, R. F. A., Jacobs, C. M. J., Moors, E. J., and Kabat, P.: Modelling the effect of aggregates on $\mathrm{N}_{2} \mathrm{O}$ emission from denitrification in an agricultural peat soil, Biogeosciences, 8, 2649-2663, doi:10.5194/bg-8-2649-2011, 2011.

Svensson, B. H. and Sundh, I.: Factors affecting methane production in peat soils, Suo., 43, 183-190, 1992.

Tiemeyer, B., Freibauer,A., Drösler, M., Albiac-Borraz, E., Augustin J., Bechtold, M., Beetz, S., Belting, S., Bernrieder, M., Beyer, C., Eberl, J., Eickenscheidt, T., Fell, H., Fiedler, S., Förster, C., Frahm, E., Frank, S., Giebels, M., Glatzel, S., Grünwald, T., Heinichen, J., Hoffmann, M., Hommeltenberg, J., Höper, H., Laggner, A., Leiber-Sauheitl, K., Leppelt, T., Metzger, C., Peichl-Brak, M., Röhling, S., Rosskopf, N., Rötzer, T., Sommer, M., Wehrhan, M., Werle, P., and Zeitz, J.: Klimarelevanz von Mooren und Anmooren in Deutschland: Ergebnisse aus dem Verbundprojekt "Organische Böden in der Emissionsberichterstattung", Thünen Working Paper, No. 15, http:// nbn-resolving.de/urn:nbn:de:gbv:253-201311-dn052806-7 (last access: April 2014), 2013.

Tiemeyer, B., Borraz, E. A, Augustin, J., Bechtold, M., Beetz, S., Beyer, C., Eickenscheidt, T., Drösler, M., Förster C., Freibauer, A., Giebels, M., Glatzel, S., Heinichen, J., Hoffmann, M., Höper, H., Leiber-Sauheitl, K., Rosskopf, N., and Zeitz, J.: Greenhouse gas budgets for grasslands on peatlands and other organic soils, Geophys. Res. Abstr., Vol. 16, EGU2014-14825, 2014, EGU General Assembly, 2014.

Tietema, A., Warmerdam, B., Lenting, E., and Riemer, L.: Abiotic factors regulating nitrogen transformations in the organic layer of acid forest soils: Moisture and pH, Plant Soil, 147, 69-78, 1992.

Tjoelker, M. G., Oleksyn, J., and Reich, P. B.: Modeling respiration of vegetation: evidence for a general temperature-dependent $\mathrm{Q}_{10}$, Global Change Biol., 7, 223-230, 2001. van Beek, C.L., Pleijter, M., Jacobs, C. M. J., Velthof, G. L., van Groenigen, J. W., and Kuikman, P. J.: Emissions of $\mathrm{N}_{2} \mathrm{O}$ from fertilized and grazed grassland on organic soil in relation to groundwater level, Nutr. Cycl. Agroecosyst., 86, 331-340, 2010.

van Beek , C. L., Pleijter, M., and Kuikman, P. J.: Nitrous oxide emissions from fertilized and unfertilized grasslands on peat soil, Nutr. Cycl. Agroecosyst., 89, 453-461, 2011.

Veenendaal, E. M., Kolle, O., Leffelaar, P. A., Schrier-Uijl, A. P., Van Huissteden, J., Van Walsem, J., Möller, F., and Berendse, F.: $\mathrm{CO}_{2}$ exchange and carbon balance in two grassland sites on eutrophic drained peat soils, Biogeosciences, 4, 1027-1040, doi:10.5194/bg-4-1027-2007, 2007.

VDLUFA: Bestimmung von mineralischem (Nitrat-)Stickstoff in Bodenprofilen (Nmin-Labormethode), in: Methodenbuch Teil 2, VDLUFA, Speyer, Germany, 1997.

Velthof, G. L., Brader, A. B., and Oenema, O.: Seasonal variations in nitrous oxide losses from managed grasslands in the Netherlands, Plant Soil, 181, 263-274, 1996.

Vuichard, N., Soussana, J.-F., Ciais, P., Viovy, N., Ammann, C., Calanca, P., Clifton-Brown, J., Fuhrer, J., Jones, M., and Martin, C.: Estimating the greenhouse gas fluxes of European grasslands with a process-based model: 1. Model evaluation from in situ measurements, Global Biogeochem. Cy., 21, GB1004, doi:10.1029/2005GB002611, 2007.

Welles, J. M., Demetriades-Shah, T. H., and McDermitt, D. K.: Considering for measuring ground $\mathrm{CO}_{2}$ effluxes with chambers, Chem. Geol., 177, 3-13, 2001

Whalen, S. C.: Biogeochemistry of methane exchange between natural wetlands and the atmosphere, Environ. Engin. Sci., 22, 7394, 2005.

Worrall, F., Burt, T. P., Rowson, J. G., Warburton, J., and Adamson, J. K.: The multi-annual carbon budget of a peat-covered catchment, Sci. Total Environ., 407, 4084-4094, 2009.

WRB, 2006 - IUSS Working Group: World Reference Base for Soil Resources 2006, 2nd Edn., World Soil Resources Reports No. 103, Rome, 2006.

Zehlius-Eckert, W., Schwaiger, H., and Beckmann, A.: Monitoring und Erfolgskontrolle im Freisinger Moos, Bayer. Akad.f. Naturschutz u. Landschaftspflege - Laufen /Salzach 2003, Laufener Seminarbeitr., 1/03, 147-170, 2003. 